\title{
Negligent Murder-Some Stateside Footnotes to Director of Public Prosecutions v. Smith
}

\author{
Rex A. Collings, Jr:*
}

T T Is NOT my purpose to add to the spate of literature, usually critical, 1 spawned by Director of Public Prosecutions v. Smith ${ }^{1}$ and its forebear, Regina v. Ward. ${ }^{2}$ When one tackles the job of criticizing the Englisll, it beliooves him to see if his own house is in order. I will review the English developments and examine American authorities as well, in the light of the English decisions. As will appear, our own approach to the "negligent" murder leaves something to be desired. So I will also examine the Model Penal Code to ascertain whether it offers a rational solution to the problem.

\section{BACKGROUND OF THE PROBLEM}

Before getting into Smith and Ward it seems desirable to attempt to identify the problem of negligent murder and examine some of the background materials.

Murder as developed under the common law of England is defined as unlawful homicide with malice aforethought. Manslaughter is unlawful homicide without malice aforethought. ${ }^{3}$ These vague definitions have been retained in nearly every American jurisdiction. ${ }^{4}$ Some statutes merely spe-

* Professor of Law, University of California School of Law, Berkeley; Special Consultant, American Law Institute Model Penal Code Project.

1 [1960] 3 Weekly L.R. 546 (H.L.); 1960 CAMr. L.J. 140; 3 CrRM. L.Q. 305 (1960); 1960 Crns. L. Rev. (Eng.) 765; 25 J. Crnas. L. (Eng.) 39 (1961); 23 Modern L. Rev. 678 (1960); 104 Sox. J. 946 (1960); Williams, Constructive Malice Revived, 23 ModerN L. REv. 605 (1960).

The decision in the Court of Criminal Appeal was reported under the title, Regina v. Smith, [1960] 3 Weekly L.R. 93 (C.C.A.); 3 Crmor. L.Q. 176 (1960); 1960 Crnor. L. Rev. (Eng.) 491, 24 J. Crom. L. (Eng.) 196 (1960); 76 L.Q. REv. 195 (1960).

Neither this list nor the list in note 2 is intended to be exhaustive .

2 [1956] 1 Q.B. 351; 1956 CrnM. L. REv. (Eng.) 203; 20 J. CREM. L. (Eng.) 159 (1956); 72 L.Q. REv. 166 (1956); 19 MODERN L. REv. 414 (1956); Lowe, Mfurder and the Reasonable Man, 1958 Crons. L. REv. (Eng.) 289, 374, 453; Prevezer, Murder by Mistake, 1956 Crms. L. REv. (Eng.) 375.

3 Stephen, Digest of Crmmnat Law art. 223 (1877).

$4 \mathrm{New}$ York in its statutory treatment has departed from common-law terminology to some extent. N.Y. PEN. LAW §§ 1042-53. The statutes of Kansas, Minnesota, North Dakota, Oklahoma, and South Dakota follow the New York pattern. Three other states have attempted redefinitions of homicide. See LA. REv. STar. \$\$ 9-14:29-31 (1951); TEx. PEN. CodE arts. 123041, 1256 (1948); WIs. STar. ANN. \$§ 940.01-03, 940.05-06 (1958). 
cify the sentences that may be imposed for murder and manslaughter without defining the crimes. If murder is divided into degrees, the first degree category is defined; all other kinds of murder are declared to be of the second degree. ${ }^{5}$ The common-law concept of malice aforethought is written into such statutes by judicial decision..$^{B}$ Another common statutory treatment is to distinguish murder from manslaugliter by the presence or absence of malice aforethought, either with or without definition of that term. Again, if murder is divided into degrees the first degree category is defined and other murders declared to be of the second degree. ${ }^{7}$

The Georgia statute is a good exaniple of the typically vague definition of murder and inahice aforethought:

Murder is the unlawful killing of a human being, in the peace of the State, by a person of sound memory and discretion, with malice aforethought, either express or implied.

Express malice is that deliberate intention unlawfully to take away the life of a fellow creature, which is mamifested by external circumstances capable of proof.

Malice shall be implied where no considerable provocation appears, and where all the circumstances of the killing show an abandoned and malignant heart. ${ }^{8}$

Malice aforethought, according to Stephen, means any one or more of the following states of mind:

(a) An intention to cause the death of, or grievous bodily liarm to, any person, whether such person is the person actually killed or not;

(b) Knowledge that the act which causes death will probably cause the death of, or grievous bodily harm to, some person, whether such person is the person actually killed or not, although such knowledge is accompanied by indifference whether death or grievous bodily liarm is caused or not, or by a wisl that it may not be caused;

(c) An intent to commit any felony whatever;

(d) An intent to oppose by force any officer of justice [within specified limits]. ${ }^{\circ}$

Malice aforethought, thus, is a technical expression, a shorthand symbol for a number of different states of mind. Stephen's first category causes little trouble. The common law assimilated imtent to do grievous bodily harm with intent to kill. ${ }^{10}$ This draws little dissent. There is no reason to distinguish between a killer who intends to cause death and one who intends

5 See, e.g., Pa. Stat. ANr. tit. $18 \$ 4701$ (Supp. 1960).

${ }^{6}$ See, e.g., Commonwealth v. Drum, 58 Pa. 9 (1868).

7 See, e.g., CaI. Pen. Code $§ \S 187-89$.

$826 \mathrm{GA}$. CODE $§ \S 1002-04$ (1933).

0 Stephen, Digest of Crmanar Law art. 223 (1877).

${ }^{10}$ See, e.g., Rex v. Grey, Kel. 64, 84 Eng. Rep. 1084 (1666) (correction of servant by striking him with an iron bar). 
to cause serious bodily harm. Stephen's third and fourth categories are troublesome, but beyond the scope of the present article. Most will agree that homicides in the course of commission of a felony or resisting arrest were murder at common law. Controversy over these doctrines involves questions of their limits at common law, or whether they should be retained.

Stephen's second category is troublesome. Must the killer actually have foreseen the consequences of his act to be a murderer? Shortly after Stephen's work was published, Holmes published The Common Law, in which he elaborated on and practically obliterated Stephen's second category. He sought to reduce foresight of consequences to what he called "lower terms":

If the known present state of things is such that the act done will very certainly cause death, and the probability is a matter of common knowledge, one who does the act, knowing the present state of things is guilty of murder, and the law will not inquire whether he did actually foresee the consequences or not. The test of foresight is not what this very criminal foresaw, but what a man of reasonable prudence would have foreseen.11

In other words, according to Holmes, there can be a negligent murder. If the actor has knowledge of facts which make his act dangerous, and if he causes death, he is a murderer if a person of ordinary prudence would have foreseen death whether or not he in fact foresaw it. Stephen seems to require foresight of consequences. Holmes definitely does not.

The problem of this article can now be stated as follows: Under what circumstances should a killer be convicted of murder when he lacks intent to kill, intent to injure seriously, intent to commit a felony or intent to resist arrest? Must he actually foresee death as a result of his act? Or should it suffice that a reasonable man would have foreseen death? Can one negligently commit murder?

At this point a brief excursion into the background materials seems to be in order. Did the common law recognize the equivalent of the negligent murder? Cases before the 19th century are of little help, so one falls back on the writers. Coke, writing in 1628, said,

If a man knowing that many people come in the street from a sermon, throw a stone over a wall, intending only to feare them, or to give them a light hurt, and thereupon one is killed, this is murder; for he had an ill intent, though that intent extended not to death, and though he knew not the party slaine. ${ }^{12}$

Coke does not express his views, if any, on foresight of the consequences. However, intent to scare as of a practical joker could certainly exist in the absence of foresight of the fatal consequences. It would appear, therefore,

11 HOLMES, THE CONOMON LAW 53-54 (1881).

12 Coke, ThiRd Institute 56. 
that he offers support for the view that there could be negligent murder at common law.

Hawkins, publishing early in the 18th century, said,

Neither shall he be adjudged guilty of a less crime [than murder] who kills another, in doing such a wilful act, as shews him to be as dangerous as a wild beast, and an enemy to mankind in general; as by going deliberately with a horse used to strike, or discharging a gun, among a multitude of people, or throwing a great stone or piece of timber from a house into a street through which he knows that many are passing; and it is no excuse that lie intended no harm to any one in particular, or that he meant to do it only for sport, or to frighten the people. ${ }^{13}$

Again it appears that the test is objective. Conceivably a practical joker can be as dangerous as a wild beast, without actual foresight of the fatal consequences likely to follow from his act.

Hale, whose Pleas to the Crown was published after his death in 1736, did not discuss foresight. In the course of his discussion of involuntary inanslaughter, however, he states,

If a man knowing that people are passing along the street throws a stone, or shoots an arrow over the house or wall, with intent to do hurt to people, and one is thereby slain, this is murder, and if it were without such intent, yet it is manslaughter, and not barely per infortunium, because the act itself was unlawful ....

$A$. drives his cart carelessly, and it runs over a child in the street, if $A$. have seen the child, and yet drives on upon him, it is murder; but if he saw not the child, yet it is manslaughter ....

If a man or boy riding in the street whip his horse to put him into speed, and run over a child and kill him, this is homicide, and not per infortunium, and if he rid so in a press of people with intent to do hurt, and the horse had kild another, it had been murder in the rider. ${ }^{14}$

Thus, in one example, Hale requires an intent to injure. But in the others the determination seems based on the objective facts.

Foster who published in 1762 had this to say, "I believe most, if not all the cases which in our books are ranged under the head of implied malice will, if carefully adverted to, be found to turn upon this single point, that the fact hath been attended with such circumstances as carry in them the plain indications of a heart regardless of social duty and fatally bent on mischief..$^{15}$ At a later point, expounding on "Homicide occasioned by accident which human prudence could not foresee or prevent, improperly called chance-medley," he states,

131 Hawkins, Preas of tre Crown 113 (Leach ed. 1788).

141 Hate, Pleas of the Crown 474-76 (1st Am. ed. 1847).

15 Foster, Crown Law 257 (1762). 
In order to bring the case within this description, the act from which death ensueth must be lawful. For if the act be unlawful, $I$ mean if it be malum in se, the case will amount to felony, either murder or manslaughter, as circumstances may vary the nature of it. ...

If an action unlawful in itself be done deliberately and with intention of mischief or great bodily harm to particulars, or of mischief indiscriminately, fall it where it may, and death ensue against or beside the original intention of the party, it will be inurder....

A person driving a cart or other carriage happeneth to kill. If he saw or had timely notice of the mischief likely to ensue, and yet drove on, it will be murder. For it was wilfully and deliberately done. Here is the heart regardless of social duty, which I have already taken notice of. ${ }^{10}$

Foster, of course, does not allude to foresight of consequences, but he does draw a line between murder and manslaughter in language which has been used in many cases. It is murder if the killing is accompanied by circumstances which indicate "a heart regardless of social duty and fatally bent on mischief." Does this language permit a conviction of negligent murder? This is the crux of the problem, as will appear. If the surrounding circumstances indicate that the defendant was fatally bent on mischief he will usually have foreseen such fatal mischief. But is this necessarily so? Foster's test appears to be objective.

Blackstone in a portion of his treatise published in 1769 wrote,

Express malice is when one, with a sedate deliberate mind and formed design, doth kill another, which formed design is evidenced by external circumstances discovering that inward intention; ... Neither sliall he be guilty of a less crime who kills another in consequence of such a willful act as shows him to be an eneiny to all mankind in general; as going deliberately, and with an intent to do mischief, upon a lorse used to strike, or coolly discharging a gnn, among a multitude of people. ${ }^{17}$

As authority he cites Hawkins and the argument in Rex v. Keite..$^{18}$ In that case defense counsel are reported arguing as follows: "A. knowing that many people are coming in the street from a sernion, casts a stone over the wall intending only to frighten them ... [Coke] says, that this is murder; but that is not law, for to make inurder there must be an intent to kill [citing Hale]." The report then reads as follows: "(Holt, Chief Justice, agreed with this, and said that the opinion of Coke... was too general, and ought to be qualified with the distinction that my Lord Hale makes . . . where the act is done with a design to do mischief to any, and where not.)"

This was the state of authority at the time of the American independence. However, one later treatise writer, East, was cited in some of Justice

${ }^{18} I d$. at 258, 261, 263.

174 BIACKSTONE, COMarentaRIES ON THE LAW OF ENGLAND *199-200 (Jones ed. 1916).

181 Ld. Raym. 138, 91 Eng. Rep. 989 (1696). 
Holmes's opinions, and should not be overlooked. Publishing in 1803, East recognized that there could be a general malice or a depraved inclination:

The act itself must be unlawful, attended with probable serious danger, and must be done with a mischievous intent to hurt people ... for it is from these circumstances that the malice is to be inferred. But if an unlawful and dangerous act, manifestly so appearing, be done deliberately, the mischievous intent will be presumed, unless the contrary be shewn.

He gives an example of a person, breaking an unruly horse, who wilfully rides him among a crowd of people. This is murder if someone is killed:

[T] he probable danger being great and apparent .... how can it be supposed that a person wilfully doing an act, so manifestly attended with danger, especially if he shewed any consciousness of such danger himself, should intend other than the probable consequence of such an act. But yet if it appear clearly to have been done heedlessly and incautiously only, and not with an intent to do mischief, it is only manslaughter: thougli Hawkins considers that it would be murder if the person intended to divert himself with the friglit of the crowd. ${ }^{19}$

At another point in his discussion East speaks of "homicide from impropriety, negligence or accident." Discussing fatal accidents which occur among persons following their lawful occupations, he states,

If they saw the danger, and yet persisted without sufficient warning, it will be murder. If the act were such as was hikely to breed danger, and they neglected the ordinary cautions, it will be manslaughter at least, on account of such neghigence; making due allowance for the nature of the occupation, and the probability of the danger; which if very remote, and in the particular instance not reasonably to be expected, may reduce the act to misadventure. The criterion in such cases is to examine whether common social duty would, under the circumstances, have suggested a more circumspect conduct. ${ }^{20}$

Holmes used the last sentence of the above quotation out of context in Commonwealth v. Chance, ${ }^{21}$ where he said, "[R]educed to its lowest terms, malice in inurder means knowledge of such circumstances that according to common experience there is a plain and strong likelihood that death will follow the contemplated act. ..." This sentence is followed by the sentence from East making it appear that East was discussing only murder. Actually East was discussing the difference between murder, manslaughter, and unisadventure. Were it not for the phrase "at least" one might conclude that East thought that actual foresight was required for murder. Yet in his example he suggests that heedlessness or want of caution would mitigate murder to manslaughter only if there was no intent to do "mischief."

19 I East, Pleas of the Crown 231 (1806).

20 Id. at 262.

21174 Mass. 245, 252, 54 N.E. 551, 554 (1899). 
East gives two additional examples. Speaking of homicides caused by workmen who throw stones and rubbish from a house in the course of their business, he says, "[I]f they deliberately saw the danger, or betrayed any consciousness of it, from whence a general malignity of heart might be inferred, and yet gave no warning, it will be murder, on account of the gross inipropriety of the act." 22 A person driving a carriage who kills another is a murderer "if he saw or had timely notice of the mischief likely to ensue, and yet wilfully drove on ... for the presuniption of malice arises from the doing of a dangerous act intentionally: there is the heart regardless of social duty." ${ }^{23}$ Certainly in both of these cases the actor was conscious that he was doing a dangerous and uulawful act. Perhaps when Holmes relied on East for his theory of neghigent murder he was leaning on a weak reed.

One reviews these old authorities with some misgivings because of the scarcity of citation of authority. Yet, so far as can be discovered there was very hittle in the way of decisional authority. And it is certain that these writers had a tremendous influence on our own decisions, as well as on our statutes.

If one rereads these quotations several times he will not be compelled to conclude that there could be a neghigent murder at common law. However, he will be satisfied that for the nost part these writers had no interest whatsoever im subjective intent. For example, Foster was interested in plain indications of a heart regardless of social duty and fatally bent on mischief. Blackstone too was concerned with intent to do mischief.

Perhaps one of the reasons these writers were so imterested in objective mamifestations was that the defendant was not entitled to give evidence in his own behalf during nuch of the period in which they wrote. He could make an unsworn statement but was incompetent to testify. ${ }^{24} \mathrm{He}$ became a competent witness in Maine.in $1864 .{ }^{25}$ Most other American jurisdictions gradually followed Maine, for example, California in $1866 .^{28}$ The English statute came in $1898 .{ }^{27}$ Even today the defendant cannot testify in his own behalf in Georgia. ${ }^{28}$

The factor of the presumption of malice also made the state of mind of the defendant relatively unimportant. Foster stated the presumption as follows: "In every charge of murder, the fact of killing being first proved, all the circumstances of accident, necessity, or infirmity, are to be satisfac-

221 East, Pleas of the Crown 262 (1806).

23 Id. at 263.

24 See, e.g., Coleman's Trial, 7 Howerd, State Trials 1, 65 (1678).

25 Me. Stat. ch. 280 (1864).

26 Cal. Stat. ch. 644, p. 865 (1856).

2761 \& 62 Vict. c. 36 (1898); see Willaams, The Proof of GuIrr 35, 46 (1955).

28 Ferguson v. Georgia, 29 L.W. 4281 (1961). 
torily proved by the prisoner, unless they arise out of the evidence proved against him; for the law presumeth the fact to have been founded in malice, until the contrary appeareth." ${ }^{29}$ Chief Justice Shaw stated it somewhat more narrowly: "The natural and necessary conclusion and inference from such an act [homicide] wilfully done, without apparent excuse, are, that it was done malo animo, in pursuance of a wrongful injurious purpose, previously, though perhaps suddenly, formed, and is therefore 'a homicide with malice aforethought' ...." ${ }^{\prime 30}$ The presumption arises even in cases which are classified under the title of implied malice: "When a liomicide is committed under circumstances of great barbarity and cruelty, such brutal malignity supplies the place of malice and makes the act of killing the equivalent of a deliberate act of slaughter." ${ }^{31}$

The effect of implying malice in the case of a homicide resulting from the doing of some dangerous act is equivalent to applying an objective test of extrinsic danger of the act. The only way the killer can rebut the presumption is to slow provocation, justification or excuse. He does not rebut the presumption by showing lack of an actual intent to kill or to injure seriously. ${ }^{32}$

\section{THE WARD CASE}

The early text writers, as we have seen, approached the problem of the negligent murder rather crudely and ambiguously. They had scant authority for their opimions. Yet they undoubtedly had considerable influence on the law, particularly in this country. Until recently the decisional law in England was unsettled. Then came the Ward case like a bolt out of the blue.

Ward, admittedly a man of subnormal intelligence, was living with a woman not his wife and her child of eigliteen months. He came home tired from his work and had to repair a bed. The woman left hin with the child for fifteen minutes. When she returned the child was dead. Ward testified that he took off the mattress in order to repair the bed. He placed the child

29 Foster, Crown Cases 255 (1762).

30 Commonwealth v. York, 9 Met. 93, 104 (Mass. 1845).

312 Bishop, Crtartnat Law 512 (1923); accord, Commonwealth v. Drew \& Quinby, 4 Mass. 391 (1808) ("If the act of killing was in itself attended with probable dangerous consequences to the deceased, and was committed deliberately, the malice will be presumed, unless some sufficient excuse or provocation be shown...."). But see MicHaer \& WeCHSLER, CrmardaAL LAW AND ITs ADMmIISTRATION 39 n.3 (1940). The authors suggest that for the presumption to arise the prosecution must show that the homicide was committed intentionally, or at least with a deadly weapon.

32 See also the discussion and authorities cited in N.Y. LAW REv. Comm., Comparonication AND StUDY RELATING to Homicme 19-26 (1937). The author concludes that the presumption in the case of homicides caused by extreme negligence or recklessness was an irrebuttable presumption of law. 
on it. The child was crying. Ward testified she was "always crying, continually crying." His ulcers were bothering him. As a result of the combination of being tired, having to repair the bed, his ulcers and the crying, he lost his teinper. Using his full force he shook the child, causing her death. He had no intention of killing or hurting her. He merely wanted to quiet her. The trial judge charged as follows:

If, when he did the act which he did do, he must as a reasonable man have contemplated that death or grievous bodily harm was hikely to result to the child as a result of what he did, then ... he is guilty of murder. If, on the other hand, he could not, as a reasonable man, have contemplated that death would result in consequence of what he did, then he is guilty of manslaughter. In law a man is presumed to intend the natural consequences of his act, and if he therefore acts in a fashion in which a reasonable man would contemplate that he would do serious injury to the child, a child of 18 months, and death results, then he is guilty of murder. But you have got to be satisfied about that, and satisfied upon the evidence so that you can say you feel sure that this man must have contemplated in doing what he did that he would seriously injure this child .... .33

The reasonable man portion of the instruction must have been significant, because after deliberating three hours the jury asked for a repetition of it. Seemingly the court read at that point the substance of the first sentence quoted above. The jury promptly returned a verdict of murder.

On appeal it was argued that the jury was misdirected, that the primary matter to be considered was what was in the mind of the accused himself, and what he, with his particular peculiarities and mentality, thought or contemplated. Chief Justice Goddard interrupted the argument by saying, "That is setting up a varying standard." Counsel for the crown were not called upon. The Lord Chief Justice delivered a judgment from the bench dismissing the appeal. He said the summing-up was unimpeachable and to his knowledge had been given in scores of cases. None were cited. He adopted a reasonable man test for murder, as follows:

Of course, the test must be applied to all alike, and the only measure that can be brought to bear in these matters is what a reasonable man would or would not contemplate. If the act is one as to which the jury can find that a reasonable man would say: "It would never occur to me that death would result or grievous bodily harm would result," then the jury can find him guilty of manslaughter; but if the jury come to the conclusion that any reasonable person, that is to say, a person who cannot set up a plea of insanity, must have known that what he was doing would cause at least grievous bodily harm, and the death is the result of that grievous bodily harm, then that amounts to murder in law and a verdict of murder is justified. ${ }^{34}$ 


\section{III}

THE SMITH CASE

Four years later came the Smith case. The facts can be summarized as follows: Smith accompanied by another man was driving an automobile through an area on the outskirts of London. In the trunk and back of the car were stolen scaffolding clips. The car was stopped by a police officer in the normal course of traffic control. Another officer who knew Smith walked up to the driver's window and spoke to him. Apparently lie saw the clips and asked Smith to pull over to the side which he started to do with the officer walking beside the car. Suddenly Smith accelerated with the officer hanging on despite the want of a runming board. The officer let go 130 yards further on and died of injuries suffered from falling under a vehicle coming from the opposite direction. The street was twenty-seven and one-half feet wide. There was evidence that four cars were coming from the opposite direction, that Smith was zigzagging, that the officer banged against the oncoming cars, that Smith reached a "terrific" speed and that Smith may have tried to push the officer off. Although the court does not allude to this, the fact that a traffic officer was on duty leads to an inference that traffic could not have been liglit.

Smith and his companion drove on 200 yards to dump the clips. Smith then drove back to the scene of the accident. He said he did not mean to kill the officer, but did not want him to find the clips. He claimed he was frightened, and put his foot on the accelerator instead of the brake, that the swerving was due to the weiglit of the load. There was evidence, which Smith denied, that at the time of his arrest Smith said that he only wanted to sliake the officer off.

In this state of the evidence the trial judge cliarged the jury in part as follows:

The intention with which a man did something can usually be determined by a jury only by inference from the surrounding circumstances including the presumption of law that a man intends the natural and probable consequences of his acts....

If you feel yourselves bound to conclude from the evidence that the accused's purpose was to dislodge the officer, then you ask yourselves this question: Could any reasonable person fail to appreciate that the likely result would be serious harm to the officer? If you answer that question by saying that the reasonable person would certainly appreciate that, then you may infer that that was the accused's intention, and that would lead to a verdict of guilty on the charge of capital murder. ${ }^{35}$

The judge noted that the defendant challenged the statement alleged 
to have been made by him about wanting only to shake off the officer. He then said,

[I]f you are satisfied that when he drove his car erratically up the street, close to the traffic on the other side, he must as a reasonable man have contemplated that grievous bodily harm was likely to result to that officer still clinging on, and that such harm did happen and the officer died in consequence, then the accused is guilty of capital murder, and you should not shrink from such a verdict because of its possible consequence. ${ }^{36}$

The Court of Criminal Appeal in an ingenious judgment distinguished the Ward case and substituted a verdict of manslaughter for the verdict of capital murder. That court took the view that the presumption that a man intends the natural and probable consequences of his acts is a presumption which varies in its effect. Under the facts of the Smith case it is rebuttable. A distinction is to be made in applying that presumption between cases where serious injury is certain and cases where it is only likely. Ward was a case of certain injury, a case where any sane man must have known that what he was doing would cause at least grievous bodily harm. The harm was certain, and there was no evidence which could rebut knowledge of that certainty. This the court thought was the true rationale of the decision in Ward. On the other hand, in Smith, if the jury took the view that he deliberately tried to drive the officer against oncoming cars, it might have felt injury was certain and could have inferred intent. But had they concluded he merely swerved or zigzagged to shake off the officer, or did not realize the danger, the inference was one of likelihood of injury. In such a case, when the presumption is used, the jury should be told it can be rebutted and the court should have made it plain that the overall burden of proving actual intent continued to rest on the prosecution. The reasonable man test in such a case provides no more than a pointer toward the solution of the ultimate question, which is the actual state of mind of the defendant.

The Director of Public Prosecutions then appealed to the House of Lords which restored the conviction of capital murder. ${ }^{37}$ Viscount Kilmuir, Lord Chancellor, delivered a "speech" (I believe that is the English termi-

36 Ibid.

37 The speed with which English justice operates is in sharp contrast with our fumbling efforts, as in the Chessman case. Smith committed his crime on March 2, 1960. He was convicted of murder on April 7. The Court of Criminal Appeal heard argument for two days, rendering its judgment at the close of argument but taking additional time to prepare its judgment. The judgment was dehivered May 18. The Director of Public Prosecutions appealed to the House of Lords which heard argument for five days. Meanwhile the Home Secretary had announced that there would be a reprieve if the House of Lords re-instated the conviction of capital murder. The Lord Chancellor delivered his "speech" reinstating the earhier judgment on July 28, approximatcly a month after the last day of argument, and Smith was reprieved on August 1. Thus there was an elapsed time of five months between crime and final determination by the highest court. 
nology) which was concurred in by the other lords, including Lord Goddard who delivered the judgment in Ward. The Lord Chancellor rejected the subjective approach of the court below as a departure from the proposition upon which "the courts have always acted." He said that the jury inust make up their minds from the evidence that "the accused was unlawfully and voluntarily doing something to somebody." This unlawful and voluntary act must "clearly be aimed at someone in order to eliminate cases of neghigence or of careless or dangerous driving." He then laid down the reasonable man test for murder, as follows:

Once, however, the jury are satisfied as to that, it matters not what the accused in fact contemplated as the probable result or whether he ever contemplated at all, provided he was in law responsible and accountable for his actions, that is, was a man capable of forming an intent, not insane withim the M'Naghten Rules and not suffering from diminished responsibility. On the assumption that he is so accountable for his actions, the sole question is whether the unlawful and voluntary act was of such a kind that grievous bodily harm was the natural and probable result. The only test available for this is what the ordinary responsible man would, in all the circumstances of the case, have contemplated as the natural and probable result. 38

The Lord Chancellor stated he could find no ground on which the charge of the trial judge could be criticized. However, he apparently had some reservations concerning the use of the expression "reasonable man," since to lawyers this "connotes the man on the Clapham omnibus by reference to whom a standard of care in civil cases is ascertained." He said in judging intent this really denotes an ordinary man capable of reasoning who is responsible and accountable for his actions. He thouglit the jury understood the trial court's charge in this sense.

The Lord Chancellor also rejected the distinction made by the Court of Criminal Appeal between serious harn which was certain to result and serious harm which was likely to result. He thought that Lord Chief Justice Goddard in Ward was not considering the distinction suggested. He felt that "the true question in each case is whether there was a real probability of grievous bodily harm."

He also considered whether the jury should have been told that the presumption that a man intends the natural and probable consequences of his acts is rebuttable. To him, this presumption is merely another way of applying the test of the reasonable man. Once the defendant's knowledge of the circumstances and nature of his acts is certain, only proof of incapacity to forn an intent, insamity or diminished responsibility will rebut the presumption. Since there was no evidence of such rebutting facts, there

88 [1960] 3 Weekly L.R. at 554 . 
was no need to explain to the jury that the presumption was rebuttable. He suggested, however, that the presumption might well be omitted in charging the jury. Indeed, he pointed out, the phrase "presumption of law" and the himited ways in which it can be rebutted are only apt to confuse the jury..$^{39}$ The test of the reasonable inan is a simpler criterion.

One final point was a definition of the term "grievous bodily harm." The trial judge had instructed that this meant harm which would seriously interfere at least for a time with the health and comfort of the victim. The Lord Chancellor said "bodily harm" needs no definition and "grievous" means no more or less than "really serious." He could see no ground for treating these words differently in murder prosecutions than in other cases and requiring that the intent be to do an act obviously dangerous to life or likely to kill. This "really serious" harm need not be likely to kill but must be more than what "would seriously interfere for a time with health or comfort." However, the trial judge used the terms "serious harm" and "serious hurt" in other portions of his charge. Taken as a whole there was no misdirection. Furthermore, it would be impossible to say that the harm which the defendant must be taken to have contemplated could be anything but of a very serious nature and well within the term "grievous bodily harm."

This then is the English doctrine of negligent murder. A person is guilty of murder if three elements concur: ${ }^{40}$

(1) He must unlawfully and voluntarily do something to someone, such act clearly being aimed at someone.

(2) The act must be of a kind that will naturally and probably result in grievous bodily harm.

(3) The act must cause death.

Only in determining the presence of the first element are we concerned with the state of mind of the defendant. He need have no intention to kill or to do grievous bodily harm. It is sufficient if an ordinary man would have foreseen death or grievous bodily harm as a result of the act. It is immaterial that the defendant did not. Finally, it should not be overlooked that the act need not be dangerous to life or hikely to kill. It suffices if it will naturally and probably do really serious bodily harm.

The Lord Chancellor said he had to reject the subjective test because

${ }^{39}$ The Court of Criminal Appeal in its discussion of the presumption relied on Rex $v$. Steane, [1947] K.B. 997, and apparently used language from Hosegood v. Hosegood, 66 T.L.R. 735 (C.A. 1950). The Lord Chancellor distinguished those cases. Rex v. Steane was a treason case and it was necessary to prove an actual intent to assist the enemy. Hosegood was a case dealing with proof of constructive desertion, and the writer of the opinion was of the view that a husband is not to be found guilty of constructive desertion unless he in fact intended to bring the married life to an end. No such overall intent is required in consideration of intent to kill or do grievous bodily harm. In effect, he seems to be saying that the presumption is rebuttable in a crime requiring a specific intent.

40 See Williams, Constructive Malice Revived, 23 MOdERN L. REv. 605, 606 (1960). 
it was such "a departure ... from that upon which the courts have always acted." Upon what did he rely for authority? He relied on Ward, several earlier cases, and Justice Holmes. He distinguished what he said was the only case he could find which might possibly support the subjective test. It will serve no useful purpose to indulge in a debunking of the decisional basis of the Lord Chancellor's opinion. Glanville Williams has already done a masterful job of this. ${ }^{41}$ Besides, as Williams discreetly points out, if one criticizes the judgments of English courts at all, one nust exercise great restraint, or be in danger of being found in contempt of court. Not being noted for restraint, and being desirous of visiting England some day, I will for the most part content myself in incorporating Williams by reference trusting to his ability to protect me from a contempt citation.

Briefly, the Lord Chancellor cites a dictum from an obscure Irish arson case, Regina v. Faulkner, ${ }^{42}$ which incorrectly states the requirement of foresight in arson, Director of Public Prosecutions $v$. Beard, ${ }^{43}$ which dealt with the necessary intent in rape for purposes of the felony murder rule, Ward, and one other Court of Criminal Appeal case, Rex v. Philpot.44 Glanville Williams suggests that the Court of Criminal Appeal in Smith had evidently not regarded the latter two as controlling since they had quashed the murder conviction. Finally, the Lord Chancellor cited Rex v. Lumley. ${ }^{45}$ Lumley was an abortion lomicide case. The court in Lumley told the jury to convict of murder only if a reasonable man would have conteniplated that death or grievous bodily liarm was likely to result from the abortion. If lie would not, the defendant could only be convicted of manslaugliter. Lumley, a physician, was convicted of manslaughter as might be expected. The rather obvious purpose of the charge in Lumley was to narrow the felony inurder doctrine so as to give the jury a way of avoiding the drastic felony murder rule. Thereafter it became the custom in England to prosecute abortion homicide cases as manslaughter. ${ }^{46}$

Glanville Williams ${ }^{47}$ notes that the Lord Chancellor cited but one case to support the subjective approach to malice aforethouglit. ${ }^{48} \mathrm{He}$ goes on to cite a nunber of other cases, ${ }^{49}$ usually reports of charges of trial judges,

41 Id. at 612-16.

4213 Cox Crim. Cas. 550 (1877).

43 [1920] A.C. 479.

447 Crim. App. R. 140 (1912).

4522 Cox Crim. Cas. 635 (1911).

46 See Royal Commission on Capital Punishment 1949-1953, Report Cmd. No. 8932, at 386 (1953).

47 Williams, Constructive Malice Revived, 23 MODERN L. REv. 605, 616-17 (1960).

48 Regina v. Vamplew, 3 F. \& F. 520, 176 Eng. Rep. 234 (1862).

${ }^{49}$ See, e.g., Regina v. Horsey, 3 F.\& F. 287, 288, 176 Eng. Rep. 129 (1862); Regina v. Walters, Car. \& Mar. 164, 174 Eng. Rep. 455 (1841) (Not murder "if the circumstances are not such, that the party must have been aware that the result would be death.") ; Rex v. Errington, 2 Lew. 217, 168 Eng. Rep. 1133 (1838) ; Rex v. Machlin, 2 Lew. 225, 168 Eng. Rep. 1136 (1838). 
which also seem to support a subjective approach. Some of these cases were cited in oral argument before the House of Lords. It would seem that the Lord Chancellor was mistaken in his view that there was only one case "which could possibly be said to support the view taken by the Court of Criminal Appeal," which was such "a departure ... from that upon which the courts have always acted."

\section{IV}

THE MODERN WRITERS AND NEGLIGENT MURDER

The Lord Chancellor in Smith also relied upon what he regarded as "that persuasive authority," The Common Law, by Justice Holmes. $\mathrm{He}$ quotes at some length from that source including the part set forth earlier in this article. He could have cited a number of other distinguished Enghsh and American writers who have rejected the notion of negligent murder. To name a few, lie could have cited Stephen, J.W.C. Turner, Glanville Williams, Jerome Hall, Wechsler and Michael, or for that matter the Royal Commission on Capital Punishment.

I have already alluded to the views of Stephen. Turner, writing in the 17th edition of Kenny's Outlines of Criminal Law, argues that the prosecution in a murder case should be required to establish the subjective fact that the defendant foresaw that his conduct might cause death. This recklessness, or readiness to inflict fatal harm, is to be ascertained by the jury from evidence as to the particular hurt which he intended to inflict. This in his opinion is a question of evidence rather than of law. Unfortunately the courts in cases like Ward and Regina v.Vickers ${ }^{50}$ are treating evidence pointing to the facts to which the legal primciple will apply as though it were the definition of the principle. Turner concludes, "[A]ll this puzzling confusion arises from treating as a matter of law that which is essentially a matter of evidence." 51

Glanville Williams, in his great work on criminal law, wishes to define murder even more narrowly than Turner. He takes notice of Kenny's notion that malice aforethought included intention to do an act intrinsically likely to kill, though without any purpose of inflicting any hurt whatever. $\mathrm{He}$ questions this, particularly in its apphication to motor vehicle homicides. If any killing in the course of a dangerous act is murder, then every motor vehicle hoinicide beconies a murder. He concludes that the requirement is and should be "either the desire of death or serious harm or at least the foresight of the certainty of such harm." He would say that if the defendant merely gambles with his victim's hife, his act is inanslaugliter. There must

60 [1957] 2 Q.B. 664 (C.C.A.).

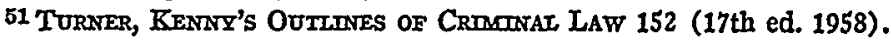


be at least foresight of the certainty of death or serious harm, not merely foresight of probability of such harm. ${ }^{62}$

Another Enghish writer who has criticized the notion of neghigent murder is Prevezer. He points to a distinction between the law of malice aforethought and the evidence required to establish it. There is a vital distinction between deliberately doing an act knowing the consequences, and deliberately doing an act in circumstances which raise a presumption that one knows the consequences. The presumption or reasonable man test can be apphied as a way of proving malice aforethought. But it slould be rebutted by proof of such factors as stupidity, drunkenness or even thoughtlessness. The result of Ward, with which he disagrees, is that a man who is stupid, or too drunk to foresee the result of his act, can be convicted of murder..$^{53}$

Smith is certainly contrary to the view of the Royal Commission on Capital Punishment, which heard testimony from many authorities, including Lord Chief Justice Goddard. The Commission in the course of defining murder, stated that murder other than felony murder requires either intent to cause death or grievous bodily harm, or knowledge that the act is likely to cause death or grievous bodily harm. It also said,

It is murder if one person kills another by an intentional act which he knows to be likely to kill or to cause grievous bodily harm, although he may not intend to kill or cause grievous bodily larm and may either be recklessly indifferent as to the results of his act or may even desire that no harm slould be caused by it. ${ }^{54}$

The Royal Commission cited two examples: It would be murder to expose a helpless infant in circumstances where there is no reasonable expectation that it will be found and preserved by someone else. It would be murder to kill persons in a street by exploding a barrel of gunpowder for the purpose of escape, even apart from the felony murder doctrine.

For the first example the Commission cited Regina $v$. Walters. ${ }^{55}$ The court in that case charged the jury that it would be for them to consider whether the child was left in such a situation that "to all reasonable appreliension, she must have been aware the child must die [which would be murder], or whether there were circumstances that would make it likely that the child would be found by some one else, and its life preserved, because then the offence of the prisoner would be manslaughter only." ${ }^{56}$

62 Witriadrs, Crminnar LaW 45-48 (1953). He cites Regina v. Walters, Car. \& Mar. 164, 174 Eng. Rep. 455 (1841), and Regina v. Vamplew, 3 F.\& F. 520, 176 Eng. Rep. 234 (1862), in support of his requirements.

E3 Prevezer, Murder by Mistake, 1956 CRar. L. REv. (Eng.) 375.

64 Royal Commission on Capital Punishment 1949-1953, Report Cmd. No. 8932, at 28.

65 Regina v. Walters, Car. \& Mar. 164, 174 Eng. Rep. 455 (1841). Walters was cited to the House of Lords in Smith, but not mentioned in the opinion.

56 Regina v. Walters, Car. \& Mar. 164, 170, 174 Eng. Rep. 455, 458 (1841). 
At another point in its report the Royal Commission pointed to the fact that some authorities, referring to two opinions by Justice Holmes, ${ }^{57}$ have held that it is not necessary for the defendant actually to foresee the consequences if he is aware of circumstances that according to common experience would make the commission of the act likely to involve great danger. The Commission said,

We do not share this view; but in practice the difference between the subjective and the objective test will be much less than would appear in theory. The jury will generally have to infer that the prisoner knew that his act was dangerous from the fact that its danger was obvious and would have been plain to any reasonable man, although he may sometimes be able to satisfy them that the inference should not be drawn. Under the existing law as stated by Stephen, the question the jury have to consider in such a case is whether the accused knew or was aware of the hikely consequences of his act; and we think that the law is sound..$^{58}$

The Commission recommended that the felony nurder doctrine be abolished. Otherwise, based on its interpretations set forth above, it found the definition of murder satisfactory and made no recommendation for revision. A careful reading of the report leads one to conclude that if the niembers of the Commission had any inkling of what would later happen in Smith they certainly would lave recommended a change in the law to elimimate the negligent murder.

Wechsler and Michael express their doubts that the common law employed an external standard in the case of nurder. However, they, as the Royal Commission, also point out that it may not make too mucl difference in practice. "Inferences as to a particular man's knowledge must usually proceed froin propositions that men like the actor would generally have, if they should act as he did under like circumstances. If the danger was great, most neen would perceive it, and, therefore, if the actor was both sober and sane, it is highly likely that he did too." ${ }^{\prime 50}$ However, they suggest, if a jury is told that it must find that the defendant created a great risk consciously, its freedom is circumscribed. Certainly it is more circumscribed than if it is instructed in the words of Justice Holmes. ${ }^{80}$

The Lord Chancellor, following the English custom of not citing living treatise writers, did not mention that the Holmes theory of objectivity in the criminal law has been placed in doubt, if not discredited, by later writers, notably Jerome Hall, who deals with the subject of recklessness and

57 Commonwealth v. Chance, 174 Mass. 245, 54 N.E. 551 (1899); Commonwealth v. Pierce, 138 Mass. 165 (1884).

58 Royal Commission on Capital Punishment 1949-1953, Report Cmd. No. 8932, at 163.

59 Wechsler and Michael, A Rationale of the Law of Homicide, 37 ColuM. L. REv. 701, 710-11 (1937).

${ }^{60}$ Note 55 supra. 
negligence in considerable detail. ${ }^{61}$ Hall of course would base criminal liability on moral culpability and limit guilt to cases of intentionality and recklessness. However, he is willing to use the reasonable man test as a method of ascertaining the existence of these states of mind. The jury can be informed that to find a defendant reckless they must find that he knew he was increasing the risk of liarm. The jury can so find if they find that a reasonable man under the circumstances would have been aware of it, unless they also find that the defendant was not aware of it. Thus, if because of defective sight or hearing or excitement the defendant was not aware that he was increasing the harm, he should be acquitted of inurder.

To Hall it is outrageous to apply the reasonable man standard in murder cases. There can be a presumption that the defendant is a reasonable man, but he should be permitted to introduce evidence to show that he was unaware of the danger. True, most cases will still be decided the same way. This will result from the use of the reasonable man test to assist in determining his subjective state of mind. It will result from the fact that in most cases the inferences drawn from the use of the reasonable man method will fit the mental state of the particular defendant on trial. It will result because the jury, in appraising the defendant's state of mind, will apply their own experience and understanding. Soine cases may be decided differently, such as Ward, where after the judge repeated his reasonable man instruction the jury quickly returned the murder verdict. Hall concludes that if the reasonable inan test was applied in this way the door would be opened to a fair and defensible adjudication.

One more writer who should be mentioned is Moreland, a proponent of neghigent murder. Moreland seems to be a disciple of Holmes, but is also a very practical man. For example, discussing the matter of homicides by intoxicated defendants he states,

[I] $t$ is apparent that courts, as well as juries, in this country show an unwillingness to allow drunkenness to afford immunity to a conviction for negligent murder if the conduct of the accused is so extremely dangerous and lighly barbarous as to warrant a conviction. If courts and juries are going to reach this result regardless of legal technicalities, it would seem better to follow the view of Holmes and frankly hold the defendant guilty because his conduct is barbarous rather than to follow Stephen's view and reach the same result by interpreting the facts so as to find knowledge of the danger, although it may not actually exist. ${ }^{62}$

The last allusion is apparently to the Beard case, ${ }^{63}$ where it was held that in the case of felony lomicide it is not necesary that the defendant

61 hati, Generai Princtples of Cramtatax Law 105-70 (2d ed. 1960).

62 Moreiand, Tre Law of Homtcide 40 (1952).

63 [1920] A.C. 479. 
have knowledge that what he is doing is dangerous if he is capable of forming the intent to commit the felony. Beard, while raping a thirteen-year-old girl, placed his hand over her mouth and pressed his thumb on her throat. She died of suffocation and shock. It was held that drunkenness would be no defense unless it could be established that at the time of committing the rape Beard was so drunk as to be incapable of forming an intent to commit that felony. Moreland said, "Logically, the same conclusion should be reached in a case of negligent murder."

\section{THE AMERICAN DECISIONS}

This has been a long introduction. I have purposely included many quotations in order to present the flavor of the various authorities, decisional and otherwise, as background for consideration of the doctrine of negligent murder as it appears in this country. There have been many reported decisions, many more than in the English courts. Discussion of a few will help to disclose the pattern they follow.

Preliminarily, we can dispose of one type of case, where there exists what Blackstone called "umiversal malice," 65 a form of "express malice." The defendant intends to kill, without selecting a particular victim. Blackstone illustrated it with the case of a man who resolves to and does kill the next man le meets. ${ }^{66}$ An American example is State v. Young, ${ }^{67}$ where the defendant fired into a crowd, killing a man. There was evidence that he had said, "I am going to kill soine God damn son of a bitch." A conviction of first degree murder was affirmed on the theory that this was a deliberate and premeditated killing. This is the proper result and is certainly not an example of negligent murder. The defendant intended to kill and said so at the time of his act, although he denied this at the trial. If his intention meets the requirements of deliberation and premeditation, he commits first degree murder. If it does not, and he acts wtihout legal provocation, the homicide will be second degree murder.

The remaining decisions to be discussed can be divided into three categories:

(A.) True negligent murder decisions. These are decisions like Smith where the court lays down a reasonable man test of foresight of the homicidal result.

64 Moreland, The LaW of HoMicide 39 (1952).

654 Biackstone, CoMmentaries on the LaW OF England *200 (Jones ed. 1916); Turner, Kenny's Outzines of Crmminal Law 136-37 (17th ed. 1958).

664 Blackstone, Comomentaries on the Laws of England *200 (Jones ed. 1916).

6750 W. Va. 96, 40 S.E. 334 (1901) ; accord, State v. Saunders, 108 W. Va. 148, 150 S.E. 519 (1929) (defendant stated he "was going to mess up somebody," or "kill all I can."). 
(B.) "Abandoned and malignant heart" decisions. This is a shorthand term for decisions where malice aforethought is equated with some harsh adjectives. If the defendant's conduct is found to demonstrate the type of state of mind described by the adjective, he is a murderer.

(C.) Subjective recklessness decisions. These are decisions where the court requires advertence to the homicidal consequences.

\section{A. True Negligent Murder Decisions}

Decisions like Smith where the court frankly lays down a reasonable man test for murder are rare. Justice Holmes in his famous dictum in Commonwealth v. Chance, ${ }^{68}$ said, "[R]educed to its lowest terms, malice in murder means knowledge of such circumstances that according to common experience there is a plain and strong likelihood that death will follow the contemplated act.... 'The criterion in such cases is to examine whether common social duty would, under the circumstances, have suggested a more circumspect conduct." "In Commonwealth v. Pierce, ${ }^{69}$ he pointed out, also by way of dictum, that the fiction of implied malice at common law ineant that a man might have to answer with his life for consequences which he neither intended nor foresaw. His failure or inability to predict the consequences was immaterial, if, under the circumstances known to him, the trier of fact thought the consequences obvious. If the danger is of the highest degree the act will be murder.

A leading case where it seems clear that there was no intention to kill or to injure seriously and perhaps not even foresight of death or serious bodily injury is Commonwealth v. Malone.$^{70}$ Malone, aged 17, procured his uncle's revolver and a cartridge which he placed in the revolver, in the chamber to the right of the firing pin. He suggested a game of "Russian Poker" to Long, aged 13. Long agreed. Malone placed the revolver against the right side of Long and pulled the trigger three times. The third time the revolver fired, resulting in Long's death. At the moment the shot fired, Malone was heard to say, "Did I hit you, Billy? Gee, Kid, I'm sorry." $\mathrm{He}$ testified that he placed the cartridge in the first chamber to the right of the firing chamber, that he did not expect the gun to fire, and that he had no intention of hurting Long, who was his friend and companion. Malone was convicted of second degree murder. The Pennsylvania supreme court in affirming the conviction said,

When an individual commits an act of gross recklessness for which he must reasonably anticipate that death to another is likely to result, he ex-

68174 Mass. 245, 252, 54 N.E. 551, 554 (1899). The quotation is from 1 East, Pleas or THE CROWN 262 (1806).

60138 Mass. 165, 178 (1884). He was proud of this dictum which he never had an opportunity to state as a holding. He even worked it into the decision of a famous Sherman Act case. Nash v. United States, 229 U.S. 373 (1913).

${ }^{70} 354$ Pa. 180, 47 A.2d 445 (1946). 
hibits that "wickedness of disposition; hardness of heart; cruelty; recklessness of consequences and a mind regardless of social duty" which proved that there was at that time in him "that state or frame of mind termed malice." 71

One can but speculate concerning Malone's state of mind. Perhaps he was supremely confident that the pistol was working properly, that he put a cartridge in the chamber to the right of the firing pin, and it was impossible therefore for the pistol to fire until he pulled the trigger six times.

The trial judge was very kind to Malone in charging the jury, perhaps because of his youth. He charged that if the evidence raised a reasonable doubt whether the killing was accidental or intentional they should acquit. The supreme court noted that intentional murder is first degree murder. The charge of the court was tantamount to requiring the Commonwealth to prove first degree murder or acquit. It said that a homicide can be accidental and still inurder if it results from a malicious act intentionally inflicted. It then illustrated the difference between accidental homicide and second degree murder. If the defendant had negligently caused Long to fall off the stool at which he was sitting and as a result Long had died, both initial act and death would be accidental. But when he knowingly pointed a revolver which he knew to contain one cartridge and pressed the trigger three times his act was not accidental, even if he had no intention to kill.

Pennsylvania seems to have enunciated a doctrine of negligent murder very similar to that laid down in Smith. The elements are as follows: There must be an intentional doing of an uncalled-for act. It must be done in reckless and wanton disregard of its likely harmful effects on others, that is, the defendant "must reasonably anticipate that death to another is likely to result." It must result in death. There was no dissent.

Another such case is People v. Crenshaw. ${ }^{72}$ Defendant had words with the victim, announced that he would kill hin for two cents, and struck hin with his fist. The victim died of a broken neck. Defendant was considerably taller and larger than the victin. In reversing a murder conviction the IIlinois court spelled out what it conceived to be the difference between murder and manslaughter, as follows:

Malice necessary to constitute a killing murder is presumed where the act is deliberate and is likely to be attended with dangerous or fatal consequences. ... Death or great bodily harm must be the reasonable or probable consequences of the act to constitute murder. . . . The defendant is presumed to have intended the reasonable and probable consequences of

71 Id. at 183,47 A.2d at 447 . The included quotation is from Coinunonwealth v. Drum, $58 \mathrm{~Pa} .9,15$ (1868).

72298 Ill. 412, 131 N.E. 576 (1921) ; cf. Brown v. Coinınonwealth, I7 S.W. 220 (Ky. 1891); State v. Shepard, 171 Minn. 414, 214 N.W. 280 (1927); Commonwealth v. Mayberry, 290 Pa. 195, 138 Atl. 686 (1927). 
his act, but death not being a reasonable or probable consequence of a blow with a bare fist he is not presumed to have intended that result, and if he did not, the crime would be manslaughter and not murder. ${ }^{73}$

The court went on to say that the disparity in size and strength of the parties was not sufficient to make death a natural or probable consequence.

\section{B. "Abandoned and Malignant Heart" Decisions}

The bulk of the cases in the area of negligent murder involve the use of various harsh adjectives apparently adapted from the early writers such as Foster, Blackstone and East. These adjectives are frequently written into statutes. Thus in New York it is first degree inurder to kill, unless justifiable or excusable, "by an act imminently dangerous to others, and evincing a depraved mind, regardless of human hife, although without a premeditated design to effect the death of any individual ...."74 Similar language appears in a number of other codes, althoughi the crime may be second degree murder, or if there are no degrees, simply murder. A number of other jurisdictions provide that malice is implied "when all the circumstances of the killing ... show an abandoned and malignant lieart." Nearly one-half of the statutes either do not define murder, or use the undefined expression malice aforethought.

It is hard to break the "abandoned and malignant heart" decisions into sub-classifications. However, with some effort a rather fuzzy line can be drawn between those where it is not clear whether the awareness of the homicidal risk is required, those where the actual state of mind of the defendant is irrelevant, and those where awareness of the lomicidal risk seems to be required. ${ }^{75}$

Perhaps the most frequently cited of the "abandoned and malignant heart" cases is Mayes v. People. ${ }^{76}$ Mayes threw a lieavy beer glass in the direction of his wife wlich hit the lighted oil lamp she was carrying, scat-

73298 Ill. at $416-17,131$ N.E. at 577-78.

74 N.Y. PEN. LAW $\$ 1044$.

75 Some of these cases are extremely difficult to place in categories. Thus, in State v. Welz, 155 Minn. 143, 193 N.W. 42 (1923), the court construed its third degree murder statute which requires an act imminently dangerous to others and evincing a depraved mind, regardless of human hife, without a premeditated design to effect death. The defendant was apparently crazy drunk, and while driving toward his home killed a pedestrian. The court said the statute was directed at acts "perpetrated with a full consciousness that they were calculated to put the lives of others in jeopardy." This sounds like subjective awareness and Moreland so classified it, yet the remainder of the opinion casts doubt on this conclusion. The court said that the statute formulates the common-law notion that malice can be inferred from such an act as is described in the statute. A man is presumed to intend the natural and probable consequences of his acts. "[H]e knew enough to start and guide his car, to fly when pursued, and to seek to escape.... The jury were justified in finding that he was guilty of something more serious than culpable negligence and that his acts evinced a depraved mind. ..." Id. at 149, 193 N.W. at 44.

70106 Ill. 306 (1883). This case should be compared with People v. Crenslaw, 298 Ill. 412, 131 N.E. 576 (1921), a later case from the same court. 
tering burning oil over her person. He made no effort to extinguish the fire. She died of burns. At his murder trial the defendant asked for an instruction that the jury should acquit if it had reasonable doubt of his intention to cause bodily harm. The trial judge preceded the requested instruction by the statement, "Unless all the circumstances of the killing ... show an abandoned and malignant heart on the part of the defendant." 77 A conviction of murder was affirmed and the instruction was approved. This was held to be murder whether he intended the glass to hit his wife, someone else, or whether he threw it with "general malicious recklessness, regarding any and all consequences." Is the test subjective or objective? The Illinois court does not make this clear, although it did say when an act is unlawful and dangerous "the presumption is [that] the mind assented to what the hand did, with all the consequences resulting therefrom, because it is apparent he was willing that any result might be produced, at whatever of harm to others." 78

Another such case is Bailey $v$. State. ${ }^{79}$ The evidence tended to show that defendant had a difficulty with one of a crowd and that he fired a gun into the crowd. His shot killed his friend. The defendant's request that the jury be required to find an intent to kill a human being was refused. The Alabama court affirmed a conviction of second degree murder. "There was evidence tending to show reckless firing of the gun into a crowd of Negroes, - the perpetration of an act greatly dangerous to the lives of others, and evidencing a depraved mind, regardless of human life, which under our statute, constitutes murder in the first degree ... ." 80

In People v. Jernatowski, ${ }^{81}$ the defendant had been drinking and evidently had some animosity toward the husband of the decedent, who had continued to work during a strike. He approached the lighted house, and was told to get away by the decedent. He fired into the house, with the homicide resulting. He was convicted of first degree murder under the New York statute. Upholding the conviction, the court held that no intent to kill is required under this portion of the statute:

Where a person, as the jury found this defendant did, aware that there are human beings in a house, fires several shots into it, knowing that some one may be killed, and with reckless indifference whether he is or not, he ought not to be relieved from the natural consequences of his act because at the time he fired he did not say or think, "I am going to kill." 82

Note the expression "knowing that some one may be killed." "May" in

77 Id. at 312 .

78 Id. at 314 .

79133 Ala. 155, 32 So. 57 (1902).

80 Id. at 157-58, 32 So. 58.

81238 N.Y. 188, 144 N.E. 497 (1924).

82 Id. at 191, 144 N.E. at 498. 
this context means to be contingently possible. This sounds hike subjective recklessness. Indeed at one point in the decision the court infers reckless indifference. It states that the statute is designed to embrace cases of a "general and indiscriminate" intent to kill. However, in another place it says "the jury certainly could say [his act] was imminently dangerous and ... evinced a wicked and depraved mind regardless of hunan life." This sounds like an objective test. There is respectable New York authority to the effect that it is not clear whether the test is subjective or objective, and the suggestion is made that this is not surprising considering the historical ambiguity and vagueness of the language of the statute. ${ }^{83}$

In Oborn v. State, ${ }^{84}$ the defendant, jealous of the relationship of his mistress and the victim, fired through a door at the victim and killed him. He requested an instruction to the effect that if he intentionally pointed the gun at some object other than at the victim and the bullet was accidentally deflected he was not gnilty. The court gave the instruction with the addition of the words "of murder in the first degree." Conviction of second degree murder was sustained by the Wisconsin supreme court. The court apparently was satisfied that the evidence, even as the defendant wished it to be interpreted, showed handling of a gun "so as to be imminently dangerous to [deceased] ... or some other human being and regardless thereof." 85

Wechsler and Michael in their discussion of whether murder requires advertence to the consequences state that American courts habitually deal with the matter ambignously. ${ }^{86}$ Cited in a footnote, is Mayes v. People. The context suggests that they thought Mayes was an illustration of a typical ambiguous approach to the problem. They inquire in the footnote, "What did the charge [in Mayes] inean to the jury?" This question reaches the heart of the problem of the "abandoned and malignant heart" cases. The jury in effect is merely told that from vicious acts they can imply a vicious mind. They are not asked, and usually not even expected, to find that the defendant actually had a vicious mind. In effect they are being asked for their own instinctive feeling about a man who would do a thing like this. As a sample of the commumity, naturally normal prudent men all, is the result sufficiently outrageous to justify the sanction of murder? In reality, this is a reasonable man test. It may be suggested that it will result in the conviction of defendants who have departed from the standard of the reasonable man by failing to advert to the consequences. Certainly it will result in the conviction of drunks and probably of stupid people. Thus,

83 N.Y. Law Rev. Conar., Conmunication and Study Retating to Honmcide 126 (1937).

84143 Wis. 249,126 N.W. 737 (1910).

85 Id. at 277,126 N.W. at 748.

86 A Rationale of the Law of Homicide, 37 Corosy. L. Rev. 701, 712 (1937). 
it appears that the "abandoned and malignant heart" cases provide an American equivalent of the Smith case.

Sometimes the "abandoned and malignant heart" decisions are written in such a way as to give the impression that the test is completely objective and that awareness of the risk by the defendant is immaterial. This has to be qualified by the fact that quite often, although not invariably, the facts are such as to make it appear that he was aware. An example is Banks $v$. State, ${ }^{87}$ a shooting case similar to the facts of the Young case, mentioned earhier, except that the defendant did not announce his purpose in advance of the killing. Defendant for no apparent reason shot at the caboose of a moving train and killed a brakeman. The evidence was held to support a conviction of murder. The Texas court said,

One who deliberately uses a deadly weapon in such a reckless manner as to evince a heart regardless of social duty and fatally bent on mischief, as is slown by firing into a moving railroad train upon which human beings necessarily are, cannot shield himself from the consequences of his acts by disclaiming malice. Malice may be toward a group of persons as well as to an individual. ${ }^{88}$

The court also said, "An examination of [defendant's] ... statement shows a dehberate unprovoked shooting into a moving train, an act which could reasonably result in the destruction of human life." 80

In State v. Trott, ${ }^{90}$ defendant, whose companions had earlier decided he was too drunk to drive, saw a policeman. Fearing arrest, the defendant told a companion, also intoxicated, to drive im his place. Driving fifty or sixty miles per hour at might in town, they struck a car full of children, killing one. At the time of the accident, defendant was asleep. The trial judge instructed the jury that defendant could be convicted of second degree murder if he had turned the car over to the companion knowing that the companion was intoxicated. The jury found him guilty of second degree murder. In affirming, the court said, "Malice ... may be inferential or imphed, imstead of positive, as when an act which imports danger to another is done so recklessly and wantonly as to manifest depravity of mind and disregard of human life." ${ }^{.11}$ It cited East's statement that a person driving a carriage who saw or had timely notice of the mischief likely to ensue, and yet wilfully drove on and killed a person, would be gnilty of murder. Of

8785 Tex. Crim. 165, 211 S.W. 217 (1919); accord, Davis v. State, 85 Tex. Crim. 163, 211 S.W. 589 (1919) (companion case).

8885 Tex. Crim. at 166, 211 S.W. at 217.

80 Id. at 168,211 S.W. at 218.

00190 N.C. 674,130 S.E. 627 (1925). Cf. Brown v. Commonwealth, 13 Ky. 372, 17 S.W. 220 (1891) ; State v. Shepard, 171 Minn. 414, 214 N.W. 180 (1927); Commonwealth v. Mayberry, 290 Pa. 195, 138 Atl. 686 (1927).

81 Id. at 679, 130 S.E. at 629. 
course this is not in point, since the defendant here was unconscious at the time of the homicide.

Moreland cites Trott as a case requiring knowledge of the danger. But all that was required was knowledge that he was turning the car over to an intoxicated conipanion, not advertence to the probability of death or serious bodily harm. From this manifested depravity of mind and disregard of human life malice could be implied. The court makes it clear that an intoxicated person is responsible for reasonable exercise of his understanding and will.

\section{Subjective Recklessness Decisions}

There remain to be mentioned the decisions which seem to require actual awareness of the homicidal danger. They are not too easy to find. Several involve motor vehicle murders, invariably with intoxicated or drinking defendants. In Hyde v. State, ${ }^{92}$ the defendant was under the influence of whisky and was zigzagging his Maxwell and had forced at least one car off the road. At a high rate of speed and with plenty of room to pass, he overtook an Austin, the driver of which started to pull off the road but was unable to avoid being hit from behind. The Austin caught fire and two passengers died of burns. The defendant continued to drive until his car broke down. He was convicted of second degree murder, and in denying a motion for new trial the trial judge said a jury could reasonably conclude that he

intentionally ran his car into the Austin or that the facts show a state of mind of the defendant that he was conscious of his acts, conscious of the impending danger surrounding him, and of the probable results of his acts, and then with a reckless indifference to the probable consequences of his acts, brought about the collision and death of the deceased. ${ }^{93}$

In affirming the conviction the Alabama court agreed that the evidence was sufficient to be submitted to the jury without alluding to the correctness of the lower court's legal rationale. It is reasonable to infer that the court agreed with this rationale, since the court quoted it at length.

Another such case, Owen v. State, ${ }^{04}$ involved a drunken driver. Driving fifty miles an hour along a highway he drove his truck onto the shoulder

82230 Ala. 243, 160 So. 237 (1935). In State v. Massey, 20 Ala. App. 56, 100 So. 625 (1924), the defendant, drunk, collided with a train killing a passenger. The court said if he knew the train was moving over the crossing and that the automobile would strike the train, and that death would probably result to one or more occupants of the car he would be guilty of first degree murder. Without this knowledge of the circumstances, if he was committing some unlawful act, such as driving at a reckless rate of speed, this would be manslaughter. An order granting bail was affirmed.

03230 Ala. at 244,160 So. at 238.

04188 Tenn. 459, 221 S.W.2d 515 (1949); accord, Sliorter v. State, 147 Tenn. 355, 247 S.W. 985 (1923). 
hitting four and killing two pedestrians who were walking in the direction facing him. He did not stop. The court sustained a conviction of second degree inurder. The court noted the drinking but said there was evidence he was calm and had attempted to escape when arrested shortly after the killings. This showed an understanding of what was going on around him. The evidence was sufficient to show that he consciously guided the truck onto the shoulder, perhaps to frighten the people. From the doing of an unlawful act directly perilous to human life "and so known to the wrongdoer ... there is implied such a high degree of conscious and willful recklessness as to amount to that malignity of heart constituting malice."05

Occasionally one discovers a non-vehicular "abandoned and malignant heart" decision where foresight of the homicidal consequence was required. In State v. Thompson, ${ }^{96}$ a Utah case, the defendant thought he had been cheated in a dice game and procured a gun. He returned to the game, displayed the gun and demanded his money back. He was intoxicated. He fired eight shots into a room full of people, killing one and wounding three others. His rather far-fetched defense was that he thought the safety was on, that he was surprised when the gun went off, and that he thought he only fired twice. One category of first degree murder in Utah is similar to the New York statute mentioned earlier. The statute was interpreted to require "a planned, designed and intentional doing of an act, which is greatly dangerous to the lives of others, knowing that the natural and probable consequences of such act would be to cause death or great bodily injury to some other person." ${ }^{97}$ The conviction of first degree murder was reversed for error in instructions.

\section{Summation}

From the foregoing it is concluded that in many Ainerican jurisdictions murder can be committed neghigently, although the cases are not unambiguous. A requirement of actual awareness of the probability of death or great bodily harm is seldom expressed, or required of the jury for that matter. Certainly, it is generally accepted by the treatise writers that murder can be neghigently committed in the United States. Hall, although largely directing his analysis to attacking the general idea that there can be criminal neghigence, notes that in 'the outrageous 'depraved heart' homicides, some courts seemed eager to apply the test of 'the reasonable man." "Mor Moreland is convinced of course that there is and should be negligent murder. ${ }^{08}$

05188 Tenn. at 468,221 S.W.2d at 519.

${ }^{96} 110$ Utah 113, 170 P.2d 153 (1946).

87 Id. at 126,170 P.2d at 160 .

98 HaIt, Generax Principles of Crmumatax Law 169 (2d ed. 1960).

${ }^{89}$ MORELAND, LAW OF HOMTICDE 36-41, 213-16 (1952). 
The writers of the current criminal law textbooks seem to be in agreement with Hall and Moreland. Perkins, without using that term, seems to assume the existence of neghigent murder. Citing Commonwealth v. Chance and the Mayes case he says that the doing of "an act under such circumstances that there is obviously a plain and strong likelihood that death or great bodily injury may result, is with malice aforethought unless done under circumstances of justification, excuse, or substantial mitigation."100 Miller states that the term malice aforethought includes "cases where a person does an act with knowledge that it will probably cause death or grievous bodily harm to some persons, although he has no intention to injure any person and may wish the contrary."101 This, he says, does not mean "that there must be actual knowledge, it is sufficient if a reasonable man under the circumstances would have known that such would be the natural and probable result of the act."102 Wingersky states it as settled that causing death by a willful act or omission which has a natural tendency to cause death or great bodily harm is murder in the absence of justifying or mitigating circumstances. The intent to kill or inflict great bodily harm will be implied without inquiry into the actual intent on the principle that a man is presumed to intend the natural and probable consequences of his acts. ${ }^{103} \mathrm{He}$ also states that the inalice necessary to constitute murder "may be implied from negligence, as from reckless and wanton conduct dangerous to life."104 Sears and Weihofen seem content to accept the statement of Justice Holmes in Commonwealth v. Chance which in effect recognizes the negligent murder. ${ }^{105}$ However, they make the observation that driving a motor velicle into a crowd and killing a person may be murder "if the danger of sucln a killing was so imminent and obvious that it can be fairly said that the driver must have contemplated it, i.e., that he actually intended to cause death, or that he knew such result was higlily probable but did not care."106 They cite East and three motor vehicle murder cases.

\section{E. California Cases}

The Califorma cases are of interest. In People v. Doyell, ${ }^{107}$ defendant and deceased quarreled over ownership of certain wood. The defendant suddeuly killed deceased with an axe. In the course of affirming a conviction for second degree murder the court discussed the nature of this crime.

100 Perkins, Crominat Law 32-33 (1957).

101 Mraler, Crominal Law 268 (1934).

102 Ibid. He cites five cases including People v. Crenshaw, discussed supra at note 68.

103 Clark \& Marshair, A Treatise on the Law of CrRates 580 (Wingersky ed. 1958).

104 Id. at 263.

105 MAY, LAW of Crnges 264 (Sears and Weihofen ed. 1938).

$106 \mathrm{Id}$. at 278 .

$10748 \mathrm{Cal} .85$ (1874). 
It recognized that there could be malice aforethought where an involuntary killing happens in the commission of an unlawful act which in its consequences naturally tends to destroy life. The slayer is presumed to be actuated by an intent which may not exist. Malice aforethought is inplied from such wanton recklessness as shows an abandoned and malignant heart.

A few years later in People v. Munn, ${ }^{108}$ defendant killed deceased with several blows of his fists. The trial judge charged,

Intent is generally inferred from the commission of the act. If a man knowingly and willfully does an act unlawful in itself, and it produces harm, the law conclusively infers that such harm is intended. The law presumes that the natural, necessary, and even possible consequences were intended by the author of the act. If of sound mind, the natural and proximate consequences. And if the act intended was unlawful, even the possible consequences. So if the act produces harm not intended, it holds him responsible for all the consequences. ${ }^{109}$

The court reversed a conviction of second degree murder, one ground being the use of the word "possible" in the charge, suggesting that a person must be presumed to intend the natural, probable, and usual consequences of his act, not just the possible consequences.

The California Supreme Court in these old cases did not make it clear whether the defendant actually must have foreseen the consequences before he can be convicted of second degree nurder. However, in some later district courts of appeal decisions such a subjective element does appear. ${ }^{\mathbf{1 1 0}}$ In People v. Hubbard, ${ }^{111}$ the court reversed a conviction of second degree murder, but by way of a dictum commented on a portion of the instructions. The instruction was to the effect that a killing in the commission of an unlawful act, the natural consequences of which are dangerous to life, is second degree murder. The court stated that this instruction was correct:

If the natural consequences of the unlawful act be dangerous to human life, then the unintentional killing will be murder, even though the unlawful act amount to no more than a misdemeanor. For if the natural consequences of an unlawful act be dangerous to life, and so known to the wrongdoer, there is implied such a high degree of conscious and willful recklessness as to amount to that malignancy of lieart which constitutes malice, and the malice aforethought which is an essential element of murder will be implied. ${ }^{112}$

In People v. Semone, ${ }^{113}$ defendant killed a trespasser at over 500 feet

10865 Cal. 211, 3 Pac. 650 (1884).

109 Id. at 215,3 Pac. at 652.

110 Some are ambiguous. See, e.g., People v. Cayer, 102 Cal. App. 2d 643, 228 P.2d 70 (1951).

11164 Cal. App. 27, 220 Pac. 315 (1923).

112 Id. at 38,220 Pac. at 320 .

113140 Cal. App. 318, 35 P. 2d 379 (1934). 
with a shot gun loaded with deer shot. He claimed he thought the gun was loaded with bird shot. The court upheld a conviction for second degree murder. It said,

The serious question in this case is whether the defendant knew, or by the exercise of ordinary care, should have known, that the pump-gun was loaded with shells containing leaden slugs, for it is entirely reasonable to assume that if he supposed they were loaded only with small bird shot he could not have anticipated that he would inflict bodily injury upon the man upon whom he fired at a distance of 535 feet. But this was a problem for the determination of the jury under the circumstances of this case. We are of the opinion that there is sufficient evidence to support the implied finding that the defendant knew the gun contained shells loaded with slugs at the time he fired the fatal shot. ${ }^{114}$

The court then discussed evidence of a previous quarrel with other trespassers who threatened to kill defendant and concluded that the defendant knew the gun was loaded with shells containing slugs. It stated,

When an unlawful act which results in death is debiberately performed by an assailant who knows that his conduct endangers the hife of another, and it is executed without provocation or sudden passion, which would reduce the offense to manslaughter malice is presumed. ${ }^{115}$

Although the court does use the expression "whether the defendant knew, or by the exercise of ordinary care, should have known," the basis of its affirmance seems to be that the defendant did know the gun contained shells used to kill deer and therefore when he fired he knew of a danger to life.

Another case which casts some slight light on this problem is People $v$. Efstathiou. ${ }^{116}$ Defendant who had just been discharged from his job waylaid his employer, knocked him down with his fist, and kicked him. The employer died either from the kick or from striking his head on the sidewalk. On appeal from a conviction of second degree murder it was contended that if the death was occasioned from striking the sidewalk, the evidence would not support the verdict. The appellate court rejected this contention, saying, "The consequences which would follow a fall upon a concrete sidewalk must have been known to appellant."117 Again it seems that the court is requirmg actual awareness of the risk, although it has not discussed this requirement at any length.

These appellate cases are interesting but should be considered in the light of instructions given to the jury. If the instructions are ambiguous, as was earlier suggested, the jury may be applying an objective or even a

114 Id. at 323,35 P.2d at $381-82$.

115 Ibid.

11647 Cal. App. 2d 441, 118 P.2d 22 (1941).

117 Id. at 443,118 P.2d at 23. 
reasonable man test. A standard California instruction reads in part as follows:

[T] he unlawful killing of a human being with malice aforethought, but without a deliberately formed and premeditated intent to kill, is murder of the second degree....

(1) When the killing results from an unlawful act, the natural consequences of which are dangerous to life, which act is deliberately performed by a person who knows that his conduct endangers the life of another, or ...

(2) When the circumstances of the killing show an abandoned or malignant heart .... 118

Perhaps such an mstruction does not make it crystal clear that the test is objective. The court never says, "It doesn't matter whether this defendant had an abandoned and malignant heart or not as long as all of the circumstances of the killing demonstrate an abandoned and malignant heart." But the plain implication is that the test is objective. And certainly it must have been so understood by many juries.

Negligent murder in California arguably can even be first degree murder when committed by poison, lying in wait or torture. The defendant may only intend to inflict suffering, not death. ${ }^{110}$ In murder by torture his intent niay be to cause cruel suffering, to punish, execute vengeance, or extort something from his victim. ${ }^{120}$ In nuurder by lying in wait there need be only lying in wait coupled with "murder."121 Although it is not clear, what seems to be required is malice aforethought, which means you are right back with the vague requirement of "an abandoned and maliguant heart." Illustrative is People v. Thomas, ${ }^{122}$ where the defendant apparently shot at or in

118 Superior Court of Los Angeles County, Caltfornia Jury Instructions, Craminai No. 305 (rev.ed. 1958). Cf. the standard definition of willful misconduct in a California guest statute case. Willful misconduct is "intentionally doing something in the operation of a motor vehicle which should not be done or intentionally failing to do something which should be done under circumstances disclosing knowledge on the part of the driver that injury to his passenger will be a probable result of his conduct or under circumstances disclosing a wanton and reckless disregard of the possible injurious results of his conduct. ... When there is a question whether a vehicle driver conducted himself with knowledge that serious injury to a guest probably would result from the conduct, proof of such knowledge does not have to come by direct evidence. The jury has the right to infer that the driver had such knowledge, if such an inference unay reasonably be drawn from the facts in evidence. ..." Cope v. Davison, 30 Cal. 2d 193, 196-97, 180 P.2d 873, 875-76 (1947). The court said that the word "infer" is synonymous with "imply." "[This] instruction allowed the jurors to draw froun the evidence the inference that a man of ordinary prudence and intelligence would have realized the probable consequences of his conduct even though Davison himself did not do so." Id. at 199, 180 P.2d at 877. Query: What is the difference between tortious wanton misconduct resulting in death and second degree murder in California, and murder in England?

119 People v. Thomas, 41 Cal. 2d 470, 261 P.2d 1 (1953).

120 People v. Tubby, 34 Cal. 2d 72, 207 P.2d 51 (1949).

121 People v. Thomas, 41 Cal.2d 470, 261 P.2d 1 (1953).

122 Ibid. 
the direction of a woman to obtain sexual gratification. She was seated at a lunch counter. He parked his car in an alley and shot her from the car with a .22 caliber rifle. His claim was that he was trying to knock a coffee cup out of her hands. There was evidence of other nonfatal shootings. A conviction of murder and death sentence was affirmed by the California Supreme Court.

Justice Traynor wrote a concurring opinion in Thomas. He added the fact that the defendant was a poor shot, and stated that under the circumstances

there can be no doubt that malice must be implied and the killing was murder. An intent to kill is not necessary for murder. Malice is implied "when the circumstances attending the killing show an abandoned and malignant heart." ... That is shown when, as here, the defendant for a base, antisocial motive and with wanton disregard for liuman life, does an act that involves a high degree of probability that it will result in death. By his own admissions defendant's conduct demonstrates that lie was not averse to endangering life for the sake of the sexual pleasure it gave him. Ouly a person with an "abandoned and malignant heart" could value the attainment of pleasure more highly than human life. ${ }^{123}$

In other portions of his opinion, Justice Traynor said there must be "intention to commit acts that involve a substantial risk of human life," and the defendant "niust intend to commit acts that are likely to cause death and that show a conscious disregard for human life." This last language sounds like his test is subjective. I would feel more certain if he had said,

(1) "does an act that he knows involves a high degree of probability that it will result in death," or

(2) "intention to commit acts that he knows involve a substantial risk of human life," or

(3) "must intend to commit acts that he knows are likely to cause death and that show a conscious disregard for human life."

VI

\section{SOME CRITICISMS OF NEGLIGENT MURDER}

By now it is no secret that I am firmly opposed to the doctrine of "negligent murder" and the American equivalent, the "abandoned and maligheart" murder. My reasons can be summarized as follows:

A. Negligent murder is contrary to modern notions of the goals of the criminal law. Penal liability should rarely if ever be imposed for results which are not intentionally or recklessly (in the sense of awareness of the risk) inflicted. Especially is this true of a crime as serious as murder. To punish a man for negligent inurder is pure retribution. Or as one commen- 
tator said, it is applying "a mechanistic, non-moral, I should almost say primitive objective standard of liabihty, based not upon actual equity but upon outward "appearances."124 Men who do not advert to the risk of death or serious bodily injury cannot be deterred by the threat of the sanction of murder. Nor are they more dangerous or in need of rehabilitation than other men who negligently engage in activities which involve homicidal risks without having the misfortune to kill.

Abandoninent of the negligent murder theory will not allow the defendant to go scotfree. Under our existing law he will be convicted of involuntary manslaughter. Perhaps negligent manslaugliter is as indefensible as negligent unurder. If so, there are other offenses for which he can be prosecuted, such as battery, driving while intoxicated or reckless driving. In this connection it slould be noted that the American Law Institute in its Model Penal Code suggests a new offense known as reckless conduct.

$B$. The negligent murder doctrine makes possible outrageous and absurd results. For example, it has been suggested that as the result of the Smith case a practical joker whose victim dies can be convicted of murder. Thus, if the defendant pulls back a cliair from under a person about to sit down, and the person falls and is killed, he would be guilty of murder. Obviously a reasonable man would have contemplated that grievous bodily liarm, particularly as that term is defined in Smith, was a probable result. ${ }^{125}$ One commentator gives an example based on a civil case where two apprentices played a practical joke on a third by turning on a compressed air pipe near his rectum. He suffered from a ruptured colon and severe shock. A reasonable inan would certainly have appreciated the probability of grievous bodily harm. Had the victim died it would clearly have been murder. ${ }^{120}$

The Ward case is illustrative of a situation where a murder conviction would be unlikely without the negligence doctrine. The jury deliberated three hours, then asked for a repetition of the particular part of the instructions which dealt with the reasonable man. Upon rehearing this instruction they speedily returned a conviction.

It is recognized that the reasonable man test or the ambiguity of the typical "abandoned and inalignant heart" instruction will usually lead to the correct result. My quarrel with the doctrine is not with the result but the way in which it is reached. Probably most of the decisions cited in this article reached the correct result. For example, it seems clear from the facts that Smith knew that his conduct would kill the officer or at least injure him seriously. However, he contended le had no intent to do either, that he was afraid of being cauglit with the stolen goods and had panicked. Why

124 Ryan, The Objective Test of Intention in Criminal Liability, 3 CRns. L.Q. 305 (1960).

125 Note, 77 L.Q. REv. 1 (1961).

1261960 CRMr. L. REV. (Eng.) 765, 766. 
not let the jury acquit him of murder and convict him of some lesser offense in the unlikely event that they believed him?

C. Negligent murder jury instructions are ambiguous and confusing. Surely some semantic niceties are desirable in instructing a jury. I have earlier alluded to the problem of the jury faced with the typical "abandoned and malignant lieart" instruction. It is ambignous since it does not tell them whether the particular defendant must have an abandoned and malignant heart. The reasonable man instruction is confusing as well. The court in Smith tried to distinguish between the negligence required for tort and the intent required for murder as adjudged by the reasonable man. It has been suggested that "a juryman who sat first in a civil trial involving negligence and then in a criminal trial involving intention defined as in this [the Smith] case would have to be schizophrenic to avoid being hopelessly confused by the two or more general standards of foreseeability."127

$D$. Negligent murder is used in England to circumvent abolition of the felony murder doctrine. The English critics lave their own special bone to pick with the Smith decision. They say it re-introduces the felony murder doctrine which was abolished with adoption of the 1957 Homicide Act. That act supposedly abolished "constructive malice," the English term for felony murder. ${ }^{128}$ It provided, "Where a person kills another in the course or furtherance of some other offense, the killing shall not amount to murder unless done with the same malice aforethought (express or implied) as is required for a killing to amount to murder when not done in the course or furtherance of another offense." It also provided that a killing in resisting an officer or arrest or in attempting an escape or rescue shall be treated as a killing in the course or furtherance of some other offense. ${ }^{129}$ At least in part this was in response to a recommendation of the Royal Commission on Capital Punishment, ${ }^{130}$

Snith was resisting arrest. Prior to 1957, a negligent or even accidental killing while resisting arrest would liave been murder under the doctrine of constructive malice. Since the killing took place after 1957 , he could not be convicted of murder under the constructive malice doctrine. However, the same result was accoinplished by finding implied inalice. The front door being locked, the Lord Chancellor slipped in the back. A companion result was that it became possible to convict Smith of capital murder.

A similar result will obtain with many felony homicides. Suppose a

127 Ryan, The Objective Test of Intention in Criminal Liability, 3 CRIM. L.Q. 305, 311 (1960).

128 TURner, Kenny's OUtinnes of Cruminat Law 140 (17th ed. 1958).

1295 \& 6 Eliz. 2, c. $11, \S 1$.

130 Royal Commission on Capital Punishment 1949-1953, Report Cmd. No. 8932, at 34-43, 45,274 . 
robber who kills his victim claims the gun went off accidentally. He aimed to do something unlawful to some one, i.e., pointed a loaded gun, death resulted, and the act was of a kind a reasonable man would foresee would probably result in death or grievous bodily harn. Even if the jury believes his story, they can convict him of murder. And this would be capital murder. Again the abolition of constructive malice and partial abolition of capital punishment is circumvented.

If a rape results $i m$ homicide it is usually because of a struggle with the viction or an attempt to quiet her screams. There is ordinarily no intent to kill or do grievous bodily harm (unless rape itself is included within that term), and in many cases no foresight of any homicidal consequences. However, the rapist is aiming an unlawful act at someone; his act is of a kind that might reasonably be foreseen to cause death or grievous bodily injury (especially as defined by the Lord Chancellor). If the victim dies, he is a murderer.

In England, then, although we no longer have the felony murder doctrine, we have a substantial equivalent. Most any homicide in the course of a common-law felony will be a murder. It will be a capital murder if it falls within the capital murder categories, the principal ones being murder in the course of theft (which includes robbery and burglary), murder by shooting, and, under specified circumstances, murders of policemen and prison guards. Glanville Williams suggests that the Smith case carries even further implications. There can now in England be a misdemeanor murder and a summary offense murder. ${ }^{131}$ To find anything quite as startling, one must go all the way back to Coke, who said, "Homicide by misadventure is when a man doeth an act that is not unlawful, which without any evil intent tendeth to a man's death. ... If the act be unlawful it is murder."182 In other words if a man does an unlawful act which from outward appearances endangers life, and kills, he is a murderer. The English have revived what Stephen called Coke's "monstrous doctrine," warranted by the authorities which he quotes." "Wh4 What Stephen had to say applies equally to the $S$ mith case. It lays down a monstrous doctrine which is entirely unwarranted by the authorities quoted. The first part of the quotation applies as well to our own "abandoned and malignant heart" doctrine, although it now has plenty of authority.

$E$. Negligent murder befuddles the already incomprehensible distinction between murder and manslaughter. In the past the man who shot into a group of people, into an occupied house or automobile, or into a railroad

131 Williams, Constructive Malice Revived, 23 MOdern L. Rev. 36 (1960).

132 COKE, THRRD INSTITUTE 56.

1333 Stepren, A History of the Crtaminat Law of England 71 (1883).

134 Id. at 57 . 
car and killed could be convicted of murder under one theory or another. The man who shot at random without any particular target was guilty of manslaugliter. Under Smith, a man who for a joke, or to celebrate a holiday, or to express his inebriated enthusiasm fires a pistol into the air from his back door takes a chance that it may be found that he should be aware of a risk that he will probably kill or do serious injury to someone. Of course the court in Smith requires a dangerous act aimed at "someone." But our man with the gun is equally dangerous and culpable, particularly if he lives in Greenwich Village. What then is the difference between murder and manslaughter under the Smith case?

The Lord Chancellor in Smith distinguished between an unlawful act intentionally aimed at "someone" and dangerous driving. Can there possibly be any logical distinction between a dangerous act intentionally aimed at "someone" and such an act aimed at "some people," or even at mankind in general? Consider, for example, Commonwealth v. Welansky. ${ }^{135}$ This case arose out of the burning of defendant's might club, the Cocoanut Grove, in Boston, in 1942 and the resulting death of 490 persons. Many of the deaths were caused by locked exit doors, at least some of which were kept locked on instructions from the defendant. The defendant was sick in a hospital at the time of the fire. He was indicted for manslaughter, involuntary manslaughter through wanton or reckless conduct. The trial judge gave, and the court approved, an instruction which included the following:

To constitute wanton or reckless conduct, as distinguished from mere negligence, grave danger to others must have been apparent and the defendant must have chosen to run the risk rather than alter his conduct so as to avoid the act or omission which caused the harm. If the grave danger was in fact realized by the defendant, his subsequent voluntary act or omission which caused the harm amounts to wanton or reckless conduct, no matter whether the ordinary man would have realized the gravity of the danger or not. But even if a particular defendant is so stupid [or] heedless ... that in fact he did not realize the grave danger, he cannot escape the imputation of wanton or reckless conduct from his dangerous act or omission, if an ordinary normal man under the same circumstances would have realized the gravity of the danger. A man inay be reckless within the meaning of the law although he himself thought he was careful. ${ }^{136}$

Another case that might be murder if Smith is correctly decided is Beeman v. State. ${ }^{137}$ Beeman was driving a heavy tractor and semi-trailer loaded with 22,000 pounds of steel castings. It was daylight, the weather was clear and the brakes were working. For some miles he had been passing signs reading, "Road under construction-Travel at your own risk." $\mathrm{He}$

135316 Mass. 383, 55 N.E.2d 902 (1944).

136 Id. at 398-99, 55 N.E.2d at 910.

137232 Ind. 683, 115 N.E.2d 919 (1953). 
rounded a curve at 55-60 miles an hour. There was a clear view for 1600 feet to a spot where a hine of vehicles was stopped by a flagman. With no more than a slight reduction in speed he crashed into the vehicles, killing one person, injuring several others and demolishing several vehicles. The court in sustaining a conviction for causing the death of another by driving a vehicle with reckless disregard for the safety of others said, "A reckless disregard for the safety of others involves a conscious choice of a course of action which injures another, either with knowledge of the serious danger to others involved therein, or with knowledge of facts which would disclose the danger to any reasonable inan." 1138

Smith required that grievous bodily harm be a probable result of the dangerous act. The trial judge had used the word "likely." Webster defines "probable" as follows: "Likely to be or become true or real; such as logically or actually may be or may lrappen; reasonably, but not certainly, to be believed or expected ...."130 "Likely," a synonym, is said to be a stronger word. "That is hikely ... which there is good reason to expect or believe; that is probable which there is more reason to expect or believe than not ...."140

Does this word "probable" form an adequate basis for distinguishing Smith from Welansky and Beeman? ${ }^{141}$ Certainly the result in both cases was reasonably to be expected. The charges asked the jury to find an extremely grave or serious danger. Of course, one can only guess what would happen if a judge submitted Welansky or Beeman to a jury on a inurder theory. A fair guess would be that convictions would not be improbable in either.

How do you distinguish a case like Beeman from some of the vehicular murder cases which have been noted earher? Is it manslaugliter merely because Beeman is a recent case and we no longer convict automobile killers of murder? Perhaps, because of the difficulty of convicting motor vehicle killers, the standard is more likely to be subjective. This would make it nore difficult to convict of vehicular manslaughter than of first degree murder, second degree inurder, and non-vehicular manslaughter, with its more severe penalties. As a matter of fact, this may be what has happened in Cahfornia. Something more closely akin to recklessness is required with

138 Id. at 689,115 N.E.2d at $922-23$.

139 Webster, New Internationax Dictionary 1971 (2d ed. 1960).

140 Id. at 1432 .

141 Query the difference between "probable" as used in Smith and "not inprobable" as used in some of our manslaughter decisions. See, e.g., Phillips v. State, 204 Ark. 205, 161 S.W.2d 747 (1942); Zirk v. Commonwealth, 189 Va. 862, 55 S.E.2d 24 (1949). The court in Beeman v. State uses the expression "serious danger." Other manslaughter cases include: State v. Bates, 65 S.D. 105, 271 N.W. 765-67 (1937) ("in all probability") ; People v. Crego, 395 Ill. 451, 70 N.E.2d 578 (1946) ("Tikely"). 
motor vehicle manslaughter, than with involuntary manslaughter, second degree murder, and first degree murder by poison, torture and lying in wait. Motor vehicle manslaughter is the hardest to prove. ${ }^{142}$ Thus, in People $v$. Costa, ${ }^{143}$ the court had to determine whether evidence of a warming by a traffic officer thirty minutes before the fatal accident was properly admitted. The court, quoting from earlier cases-interestingly enough these were not criminal cases-said,

Gross negligence has been repeatedly defined in the California cases as "the want of slight diligence," "an entire failure to exercise care, or the exercise of so slight a degree of care as to justify the belief that there was an indifference to the things and welfare of others," and "that want of care which would raise a presumption of conscious indifference to consequences."

The court continued:

An important question in the prosecution, therefore, was what Costa's actions, as related to the surrounding circumstances, disclosed concerning his state of mind. Was his act of driving at a high rate of speed after having consumed alcoholic beverages mere inadvertence, or did it disclose a conscious indifference to consequences? The fact that, less than one-half hour before the accident, an officer who stopped him called his attention to the conditions of his operator's license and the dangers of high speed driving was relevant to this issue. ${ }^{144}$

The conviction was affirmed.

A distinction between murder and manslaughter on the ground of awareness of a homicidal risk in the former and negligence in the latter has at least a basis of expedience and ease in application. But how in the world do you distinguish between the negligence required for negligent murder and that required for manslaughter? The court in Welansky, speaking of manslaughter, said that the essence of wanton or reckless conduct is intentional conduct which involves "a high degree of likelihood that substantial harm will result to another." We now say that manslaughter requires "gross negligence." Perhaps we should throw up our hands and tell the jury that murder requires "very gross negligence." Another possibility would be "grossly gross negligence."

\section{VII}

\section{TOWARD A RATIONAL SOLUTION}

What is the best way to proceed to discard the negligent murder and the "abandoned and malignant heart" murder? A writer who attacks an

142 Apparently in California "willful misconduct" is midway between "gross negligence" and "without due caution and circumspection" in the hierarchy of culpability. The most culpable of the three is gross negligence. Compare People v. Costa, 40 Cal. 2d 16, 252 P.2d 1 (1953), with Cope v. Davison, 30 Cal.2d 193, 196-97, 180 P.2d 873, 875-76 (1947), and People v. Penny, 44 Cal. 2d 861, 285 P.2d 925 (1955). 
existing doctrine should at least include a constructive proposal along with his criticisin.

It may be, as Justice Spence of the California Supreme Court has said, that we need a new statute explaining the difference between first and second degree nurder and between nuurder and manslaughter. ${ }^{145}$ But the change I suggest can be accomplished without legislation. One of the simplest ways for our California courts to accomplish it would be to disapprove the second part of the standard instruction which was set forth earlier. ${ }^{140}$ Then the court could instruct the jury that second degree murder requires "an unlawful act, the natural consequences of which are dangerous to life, which act is deliberately performed by a person who knows that his conduct endangers the life of another."

The trouble with this is that the words, "endangers the life of another," are ambiguous. What we are really trying to deter is conduct which endangers life, but want to be sure that the jury are told that this includes conduct likely to cause serious bodily injury as well as conduct likely to cause death. Bearing this in mind the instruction might be revised to read as follows: The unlawful killing of a lumian being when it does not constitute first degree nurder (assuming that has already been defined in an earlier instruction) is murder of the second degree when it results from an unlawful act, the natural consequences of which are (highly?) dangerous to life, which act is intentionally perforned by a person who knows that his conduct is likely to cause death or serious bodily injury to another. If the word "Tikely" is not considered restrictive enough some modifier or substitute can be adopted, for exanple, "very likely," "highly likely," or "in all probability." This is not intended to be a model instruction. My purpose merely is to show how readily a change can be made in our present law.

This is very similar to the approach in Utah, which is a subjective recklessness jurisdiction. Thus, in State v. Jensen, the court quotes and approves an instruction of the trial judge as follows:

Before you can find the defendant guilty of murder in the second degree, you must believe from the evidence beyond a reasonable doubt . . . that the killing was the result of the specific intention on the part of the defendant to take the life of said Val Gene Steele or with specific intention of committing the alleged unlawful act with the knowledge that the natural and probable consequences thereof would be to cause death or great bodily harm to said Val Gene Steele. ${ }^{147}$

The very anbiguity of the words "abandoned and malignant heart" facilitates change. This would not be judicial legislation. The history of the

145 People v. Valentine, 28 Cal.2d 121, 144-45, 169 P.2d 1, 15-16 (1946) (concurring opinion).

148 See text at note 118 supra.

147120 Utah 531, 537, 236 P.2d 445, 448 (1951). 
words "abandoned and malignant heart" is one of ambiguity. The old writers discussed them ambiguously and at a time when the defendant was not permitted to testify as to his actual state of mind. The old decisions are ambiguous. In a few decisions, such as the more recent California decisions mentioned earlier, courts have adopted a subjective approach.

The California cases of first degree murder by torture, lying in wait or poison can be clarified in a similar manner. Upon their actual facts they appear to be cases where an element of subjective recklessness is present. The suggested instruction for second degree murder can easily be rephrased to make it applicable in a case of reckless first degree murder by torture, lying $\mathrm{m}$ wait or poison. ${ }^{148}$

How do you prove awareness of the homicidal risk? Jerome Hall and others have suggested that the "reasonable man" test is useful in this connection. ${ }^{149}$ It is a method used to determine the existence of awareness. After giving the definition of second degree murder by acts known to be dangerous to hife, the jury could be told (again this is not proposed as a model instruction):

In order to convict, you must find that the defendant knew that his act was likely to cause death or serious bodily injury to another. Knowledge is a mental state and as such often remains hidden in the mind and is rarely capable of proof by direct evidence. It must be inferred from outward manifestations, or words or acts of the defendant, or from facts and circumstances known to him at the time of his act. You can find that the defendant knew that his act was likely to cause death or serious bodily harm if a reasonable person in his situation would have known of the danger, unless you also find that the defendant for some reason was not aware of the risk.

The notion that the reasonable man test is of utility in determining that actual mental attitude of a particular person is nothing new. Thus in the tort action of misrepresentation the problem is not whether the misrepresentation would have deceived a prudent person, but whether it was calculated to deceive the particular plaintiff. It is proper for the jury to consider whether it would have deceived a prudent man in determining whether the particular plaintiff believed in and relied upon the misrepresentation..$^{150}$

There remains to be considered the approach of the Model Penal

148 For example, Supertor Court of Los Angeles Countx, CaItFornia Jury InstrucIIONS, CRDIINAL No. 302-EE (rev. ed. 1958), could be modified to read somewhat as follows (new matter itahicized): "it is necessary that there be intentional infliction of serious bodily injury upon the person killed under circumstances known to the actor to be likely to cause... death."

148 Perhaps the first was Holdsworth who said: "So to argue is to confuse the evidence for the proposition with the proposition proved by that evidence." 3 HorDswORTH, HISTORY OF ENGIISH LAW 375 (1922).

150 See, e.g., Kempf v. Ranger, 132 Minn. 64, 155 N.W. 1059 (1916). 
Code to the problem of negligent murder. Preliminarily, it should be noted that the code rejects the notion of negligent murder as well as negligent manslaughter. It does retain a low grade felony denominated negligent homicide. $^{151}$

Under the code the reckless causing of the death of another is a criminal homicide. The definition of recklessness, insofar as relevant to homicide, is as follows:

A person acts recklessly ... when he consciously disregards a substantial and unjustifiable risk that [death] ... will result from his conduct. The risk must be of such a nature and degree that, considering the nature and purpose of the actor's conduct and the circumstances known to him, its disregard involves culpability of high degree. ${ }^{162}$

There are no degrees of murder under the code. A reckless homicide can be nurder or manslaughter. It is nurder if it is committed "under circumstances manifesting extreme indifference to the value of human life."163 Both recklessness and extreme indifference are rebuttably presumed in the case of homicides in the course of specified felonies; otherwise, both elenients nuust be proved.

Our California cases of nurder by torture, poison and lying in wait would no doubt fall within the Model Penal Code definition of nurder. Assuming proof of the subjective recklessness, the jury would find little difficulty in inferring that the defendant's recklessness demonstrated extreme indifference to the value of human life.

One possible defect in the code's homicide provision lies in its definition of criminal homicide, in relation to recklessness. It is a criminal homicide to "recklessly . . . cause the death of another." fendant must consciously disregard a substantial and unjustifiable risk that death will result. ${ }^{155}$ There is some doubt in my mind that the provision encompasses a defendant who in causing death adverts to the risk of serious bodily injury, but not to the risk of death. This state of mind is possible. In any event the defendant may claim such a state of mind. A jury instructed to find that the elements of the homicide exist beyond a reasonable doubt might acquit him of the more serious offenses and convict him of neghigent homicide. The draftsman of the code is aware of this problem, but concludes that "such cases are more satisfactorily judged by the stand-

151 ALI Model Penax Code $\$ 201$ (Tent. Draft No. 9, 1959).

152 ALI Model Penai Code $\$ 2.02$ (2) (c) (Tent. Draft No. 4, 1955).

153 ALI Model Penal Code $\S 201.2$ (Tent. Draft No. 9, 1959).

154 Id. at $\S 201.1$.

155 Apparently the causation requirements would not be met if the murder defendant could establish that he was reckless as to a risk of serious bodily harm, but not as to the risk of death. ALI Moder Penal Code $\$ 2.03$ (Tent. Draft No. 4, 1955). 
ards of recklessness and extreme recklessness as to causing death."158 I think I would feel slightly more easy about the code provision if this point were clarified.

The code approach is certainly more rational than our existing "abandoned and malignant heart" approach. However, the murder provision retains a trace of that approach. Both murder and manslaughter require advertence to the homicidal risk. Murder has an additional objective factor. The circumstances must manifest extreme indifference to the value of human life. This has some logical justification. A man who consciously disregards a homicidal risk and kills under circumstances which the jury can say manifest extreme indifference to the value of human life is a very dangerous man who should be incapacitated until it is safe to turn him loose on society. $\mathrm{He}$ is more dangerous than the man whose reckless killing does not manifest such indifference. The difficulty with this is that for reckless murder he may receive the death penalty. The Model Penal Code, on the hypothesis that the death penalty will be retained in some jurisdictions for many years to come, contains a death penalty provision. Under this provision, after determining guilt the jury is presented with additional evidence of aggravating and mitigating circumstances and then must decide whether the sentence should be death or imprisonment. ${ }^{157}$ One of the aggravating circumstances listed in the code is that the "murder was especially heinous, atrocious, or cruel, manifesting exceptional depravity."

A reckless killer, therefore, may receive the death penalty if the killing, looked at objectively, mamifested extreme indifference to life, and was especially heinous, atrocious or cruel, mamifesting exceptional depravity. It is not impossible that a reckless killer could receive the death penalty without actually being extremely indifferent to life. Thus, it is conceivable under the code that an intoxicated person who inadvertently kills can be sentenced to death. The code's concept of reckless murder or manslaughter must be read with the intoxication provision. Self-induced intoxication is equated with recklessness. "When recklessness establishes an element of an offense, if the actor is unaware of a risk of which he would have been aware had he been sober, such unawareness is immaterial." ${ }^{158}$ There is recognition and rejection of the notion that evidence of drunkenness should be admissible to negative awareness. Doubtless many killers, who were intoxicated and inadvertent to a homicidal risk, have been executed. But I find this possibihty, under the code, remote as it may seen, unacceptable. Seemingly I an in good company, since Judge Learned Hand would permit the fact of drunkenness to negative awareness of risk in all crimes requiring reckless-

150 ALI Moder Penat Code 32-33 (Tent. Draft No. 9, 1959).

167 Id. at $\$ 201.6 ; c f$. CaL. Pen. Code $\$ 190.1$.

158 ALI Model Penal Code $\S 2.08$ (2) (Tent. Draft No. 9, 1959). 
ness. ${ }^{159}$ A possible solution of the problem within the framework of the code would be to make intoxication a mitigating circumstance bearing on determination of the penalty for murder.

There may be others than drunks who may appear to be extremely indifferent to the value of human life without actually being so. Ward may have been such a person. Perhaps it would be preferable to approach the difference between murder and manslaughter from the viewpoint of awareness of the risk. This is the approach, for example, of the Indian Penal Code. One who does the homicidal act "with the knowledge that he is likely by such act to cause death commits the offense of culpable homicide" [manslaughter]. ${ }^{160}$ Such a homicide is murder if he "knows that it is so imminently dangerous that it must, in all probability cause death, or such bodily injury as is likely to cause death."101 This is really the most logical distinction between murder and manslaughter, but one difficult to articulate and apply. A jury can attempt to distinguish between acts known to be "likely" to cause death or serious bodily injury and acts known to be so dangerous that "in all probability" they will cause death or serious bodily injury. In the end result this is probably as objective as finding that the circumstances manifest extreme indifference to the value of human life, or for that matter as finding that the recklessness is gross or extreme. The draftsman of the code frankly states: "The significance of purpose or knowledge is that, cases of provocation apart, it demonstrates precisely such indifference. Whether recklessness is so extreme that it demonstrates similar indifference is not a question that, in our view, can be further clarified; it must be left directly to the trier of facts."162

The Model Penal Code offers a fairly satisfactory solution to the problem of the negligent and "abandoned and mahguant heart" murders. Neghigent murder is discarded along with nearly all of the "abandoned and maliguant heart" murder. A trace of the latter remains in the requirement of circumstances "manifesting" extreme indifference to the value of human life as an element of reckless murder. The polecat has drowned, but a faint scent lingers on. It would require but a slight change in language to make it clear that the particular defendant on trial must have been extremely indifferent to the value of life when he killed. The language might be changed to read: "Criminal homicide constitutes murder when it is committed recklessly, and such recklessness is accompanied by extreme indifference to the value of human life." With this change the "abandoned and malignant heart" will be cast into the outer darkness along with "negligent murder." This is where they rightly belong. 